\title{
Advances in high-throughput screening technology for toxicology
}

\section{Chia-Wen Hsu}

National Center for Advancing Translational Sciences, National Institutes of Health, 9800 Medical Center Drive, Bethesda, MD 20892-3375, USA

Email: amy1518@gmail.com

\section{Ruili Huang}

National Center for Advancing Translational Sciences, National Institutes of Health, 9800 Medical Center Drive, Bethesda, MD 20892-3370, USA

Email: huangru@mail.nih.gov

\section{Matias S. Attene-Ramos}

National Center for Advancing Translational Sciences, National Institutes of Health, 9800 Medical Center Drive, Bethesda, MD 20892-3375, USA

Email: attene@hotmail.com

\section{Christopher P. Austin and Anton Simeonov}

National Center for Advancing Translational Sciences, National Institutes of Health, 9800 Medical Center Drive, Bethesda, MD 20892-3370, USA

Email: austinc@mail.nih.gov

Email: asimeono@mail.nih.gov

\section{Menghang Xia*}

National Institutes of Health,

National Center for Advancing Translational Sciences, 9800 Medical Center Drive, Bethesda, MD 20892-3375, USA

Email: mxia@mail.nih.gov

*Corresponding author 
Abstract: The US Tox21 collaboration utilises a quantitative high-throughput screening (qHTS) platform to efficiently profile a large number of environmental chemicals. qHTS combined with informatics facilitates chemical prioritisation for further in-depth toxicity testing and development of computational models to predict chemical toxicity. The NIH Chemical Genomics Center (NCGC), now part of the National Center for Advancing Translational Sciences (NCATS), is a key contributor during all phases of the Tox2 1 collaboration, from assay development and compound screening to data analysis and model building. Since 2011, the Tox21/NCGC has been profiling the phase 2 Tox 21 library of approximately 10,000 (10K) environmental chemicals and drugs. The advances in HTS assays and qHTS screens against the Tox 21 's and other chemical libraries are described in this review.

Keywords: cytotoxicity; environmental chemicals; drugs; high-throughput screening; HTS; nuclear receptors; pharmacology; quantitative high-throughput screening; qHTS; structure-activity relationship; SAR; stress-response pathways; Tox21 10K library; Tox21 datasets; toxicology.

Reference to this paper should be made as follows: Hsu, C-W., Huang, R., Attene-Ramos, M.S., Austin, C.P., Simeonov, A. and Xia, M. (2017) 'Advances in high-throughput screening technology for toxicology', Int. J. Risk Assessment and Management, Vol. 20, Nos. 1/2/3, pp.109-135.

Biographical notes: Chia-Wen Hsu is currently a Commissioner's Fellow working on Medical Countermeasures (MCM) and Comprehensive in Vitro Proarrhythmia Assay (CiPA) initiatives at the US Food and Drug Administration (FDA). As a Postdoctoral Fellow at the National Center for Advancing Translational Sciences, National Institutes of Health, she conducted several Tox21-related projects under the guidance of Menghang Xia, where she used various assay technologies and informatics approaches to identify environmental chemicals and drugs that potentially modulate nuclear receptors, epigenetics, or hypoxia signaling. Prior joining NCATS, she obtained her BS in Chemistry from National Taiwan University and $\mathrm{PhD}$ in Pharmaceutical Sciences from University of North Carolina at Chapel Hill.

Ruili Huang is the informatics group lead on the toxicity profiling team at the National Center for Advancing Translational Sciences, National Institutes of Health, and the Co-Chair of the Bioinformatics Working Group of the Toxicology in the 21st Century (Tox21) initiative. Her academic background includes a $\mathrm{PhD}$ in Chemistry and a post-doctoral training in computational biology and bioinformatics. Her research interests include high throughput screening assay evaluation and prioritisation, compound structure-activity relationships, drug-gene-pathway relationships, mechanisms of chemical toxicity and in vitro to in vivo toxicity modelling.

Matias S. Attene-Ramos is an Associate Professor in the Department of Environmental and Occupational Health at George Washington University Milken Institute School of Public Health. He received his $\mathrm{PhD}$ from the University of Illinois at Urbana-Champaign. His academic training includes postdoctoral fellowships in environmental toxicology at the University of Illinois and in pharmacology and toxicology at the NIH National Center for the Advancement of Translational Sciences working for the high throughput screening initiative of the Tox 21 program. His current research interests include the improvement of toxicity testing methods for single chemicals and complex mixtures, the role of environmental chemicals in metabolic diseases, and the mechanisms of genotoxicity and carcinogenicity induced by drinking-water disinfection by-products. 
Christopher P. Austin is the Director of the National Center for Advancing Translational Sciences (NCATS) at the US National Institutes of Health. NCATS' mission is to catalyse the generation of innovative methods and technologies that will enhance the development, testing and implementation of diagnostics and therapeutics across a wide range of human diseases and conditions. Before 2012, he was the Director of the NCATS Division of Preclinical Innovation, which focuses on translating basic science discoveries into new treatments and developing new technologies and paradigms to improve the efficiency of therapeutic and diagnostic development. He founded and directed numerous initiatives including the NIH Chemical Genomics Center (NCGC), the Therapeutics for Rare and Neglected Diseases program, and the Toxicology in the 21 st Century (Tox21) program. Before joining NIH in 2002, he directed research programs genomics-based target discovery, pharmacogenomics, and neuropsychiatric drug development at Merck. $\mathrm{He}$ earned his BA in Biology from Princeton University and an MD from Harvard Medical School.

Anton Simeonov is the Scientific Director at National Center for Advancing Translational Sciences, National Institutes of Health. He earned a $\mathrm{PhD}$ in Bioorganic Chemistry, and a BA in Chemistry, and obtained a postdoctoral training at The Scripps Research Institute. He is an author and inventor on over 150 peer-reviewed scientific publications and patents, has a diverse background, ranging from bioorganic chemistry and molecular biology to clinical diagnostic research and development. Prior to joining NIH, he was a Senior Scientist at Caliper Life Sciences, a leading developer of microfluidic technologies, where he was responsible for both basic research on novel assay methodologies and development of microfluidic products for research and clinical diagnostics. He is a Literature Editor of Assay and Drug Development Technologies and a member of the editorial board of Drug Target Review. His research interests include novel detection chemistries and techniques, assays and devices for diagnostics, assay miniaturisation, and novel approaches to screening and therapeutics development.

Menghang Xia is a group leader of Systems Toxicology at National Center for Advancing Translational Sciences, National Institutes of Health. Her academic background includes a $\mathrm{PhD}$ in Pharmacology and Toxicology and a postdoctoral training in cellular and molecular immunology. She is serving as a Co-Chair in the assays/pathways working group of the Toxicology in the $21 \mathrm{st}$ Century (Tox21) program, she led the major effort to develop and validate a battery of in vitro toxicological assays in a quantitative high throughput screening platform. She is interested in studying the mechanism of action of drugs/chemicals in multiple cellular pathways and targets, such as hypoxia signalling, mitochondria function, and nuclear receptors.

This paper is a revised and expanded version of a paper entitled 'Advances in HTS' presented at Health Canada Training Seminar on Risk Science in the 21st Century, University of Ottawa, Ottawa, Canada, 4-6 March 2013. 


\section{Introduction}

As the pool of environmental chemicals and clinically-used drugs expands, it has been a challenge to quickly and efficiently profile the potential effects of such compounds on human health and the environment. Traditional toxicity testing, conducted in vivo on various animal models, provides valuable chemical safety information, but these testing methods are relatively expensive and low throughput, and sometimes it is difficult to extrapolate the test results to observations on human health due to species differences (Xia et al., 2008). The poor concordance of drug toxicities between humans and animals has also been reported (Greaves et al., 2004). Recently, high-throughput screening (HTS) has emerged as a complementary approach to probe compound actions and to prioritise chemicals for in-depth investigation. The HTS approach can be used to collect data on more than a thousand compounds per day at a much lower cost relative to in vivo experiments. More importantly, screens using human primary cells or cell lines might serve as useful indicators for compound toxicity in humans. With technological advances, human primary cells and stem cell-derived tissue specific cells are often used to screen chemicals in a HTS platform, which greatly reduces animal usage. To rapidly screen a large amount of environmental chemicals and facilitate compound prioritisation, the NCGC/NCATS focuses on implementation of assays suitable for quantitative high-throughput screening (qHTS) (Tice et al., 2013). Using qHTS to screen compounds at multiple concentrations greatly eliminates false positives and false negatives by scoring concentration-response curves of each tested compound. We have previously described and reviewed Tox 21 's efforts on assay development, robot implementation and the Tox 21 screening process (Shukla et al., 2010; Attene-Ramos et al., 2013c; Tice et al., 2013). Here we report an update of available HTS assays at the NCGC/NCATS and the recent qHTS applications.

\section{The Tox21 program at the National Center for Advancing Translational Sciences}

The NIH Chemical Genomics Center (NCGC), founded in 2004, is currently part of the Division of Pre-clinical Innovation in the National Center for Advancing Translational Sciences (NCATS). NCATS aims to translate key findings from bench to new therapeutics, to improve understanding of disease biology and drug targets, and to facilitate drug safety assessment. The mission of the centre is "to catalyze the generation of innovative methods and technologies that will enhance the development, testing, and implementation of diagnostics and therapeutics across a wide range of human diseases and conditions" (http://www.ncats.nih.gov/). It includes the development of chemical probes for novel biological mechanisms, profiling of compound libraries for biological and physiochemical properties, and invention of technologies/paradigms for assay development, screening, informatics, and chemistry. Several scientific programs exist within this space, including Assay Development and Screening Technology, Chemistry Technology, RNA Interference (RNAi), and Toxicology in the 21st Century (Tox21).

The Tox 21 program utilises expertise from multiple US federal agencies to rapidly profile a large number of environmental chemicals in multiple cellular toxicity pathways and to interpret the findings for chemical prioritisation and risk assessment. The Tox 21 partners consist of the National Toxicology Program (NTP) at the National Institute of 
Environmental Health Sciences (NIEHS), the NCGC at the NCATS, the National Center for Computational Toxicology (NCCT) at the US Environmental Protection Agency (EPA), and the US Food and Drug Administration (FDA). The major roles of the NCGC are to provide cutting-edge assay technology, to conduct qHTS against the Tox 21 compound collection, to perform data analysis, and to build predictive models of chemical toxicity. During the pilot phase, phase 1, of the Tox 21 collaboration, screening methods were optimised and assessed for suitability for screening environmental chemicals in a 1,536-well plate format. A group of cell-based assays were screened against a collection of 2,816 environmental chemicals (i.e., 1,408 provided by the NTP and 1,408 provided by the EPA) and the performances of these assays were evaluated (Tice et al., 2013). In addition, various cell-based assays were also screened against the NCGC pharmaceutical collection (NPC) comprised of 2,816 approved and investigational drugs (Huang et al., 2011a). Phase 2 of the Tox 21 program started in 2011 where the NPC compounds and additional environmental chemicals were incorporated to the Tox 21 compound collection, forming a new library of approximately $10 \mathrm{~K}$ chemicals (Tox 21 $10 \mathrm{~K}$ library). The Tox 21 phase 2 focused on the development and screening of a battery of cell-based assays with phenotypic, target-specific or mechanism-based readouts using a high-throughput or high-content screening (HCS) platform. Each assay is conducted three times on three separate days against the Tox $2110 \mathrm{~K}$ library with the same compound contained in three different well locations. Three independent concentrationresponse curves are collected for each compound after primary screening (Attene-Ramos et al., 2013c). The qHTS data generated along with chemical and assay information are made publically accessible through the PubChem database (http://pubchem.ncbi.nlm. nih.gov) and other resources including CEBS (http://tools.niehs.nih.gov/cebs3/ui/) and ACToR (http://actor.epa.gov/actor/faces/ACToRHome.jsp) after internal evaluation by the Tox 21 partners. The ultimate goal of the Tox 21 program is to identify in vitro chemical signatures that could act as predictive surrogates for in vivo toxicity.

\section{Quantitative high-throughput screening}

qHTS is a powerful approach to generate reliable biological data from large chemical libraries. Unlike traditional HTS where a given compound is tested at a single concentration, qHTS tests compounds at multiple concentrations and generates concentration-response curves for hundreds and thousands of compounds in a single experiment, which greatly reduces the false positives and false negatives (Inglese et al., 2006; Attene-Ramos et al., 2013a). In order to perform automated (also referred to as online) screening successfully, selection and development of a suitable HTS assay is a key step. To meet screening requirements in terms of plate format, cell quality (i.e., mycoplasma-free certified) and assay robustness (i.e., steps, duration, temperature, format and performance), HTS assays are usually conducted in 96-well or higher density microtiter plates. Assay reagents including substrates are chemically and thermally stable in a final working condition for at least eight hours at room temperature or on an ice bath. To minimise well-to-well variation, the HTS assay steps including reagent additions, incubation time, plate transfer to incubators, and assay reading should be as short as possible and a homogenous assay format (i.e., addition only) is preferred. Cell-based assays are ideally completed within 24 hours and not more than 72 hours to limit evaporation and maintain cell health. Evaluation of the effect of dimethyl sulfoxide 
(DMSO) concentration on cell-based assays is also a critical step in the assay optimisation because compound stock solutions are normally prepared in $100 \%$ DMSO. The cell-based assays usually tolerate DMSO up to concentrations of $1 \%$ (Xia et al., $2009 \mathrm{~b})$. Good assay performance is determined by signal-to-background ratios $(\mathrm{S} / \mathrm{B}) \geq 3$-fold, coefficients of variation $(\mathrm{CV})$ across DMSO plates without compounds $\leq 10 \%$, and $Z$ ' factors (Zhang et al., 1999) $\geq 0.5$. Changes of potency indicated by $\mathrm{IC}_{50} / \mathrm{EC}_{50}$ (half maximal inhibitory concentration/half maximal effective concentration) values of positive controls should be less than three- to six-fold during day-to-day screening. In addition to assay selection and validation, automation and informatics are equally important in qHTS to ensure high quality results from a large number of samples.

Figure 1 A 3D scatter plot of the intra-plate concentration response curves of positive controls in each screening of the cell-based assays, (a) positive control curves in online agonist screens (b) positive control curves in online antagonist screens

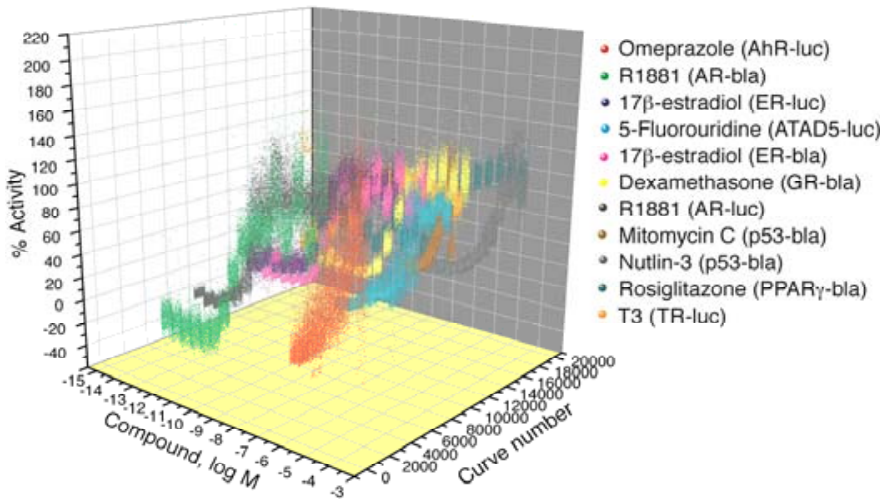

(a)

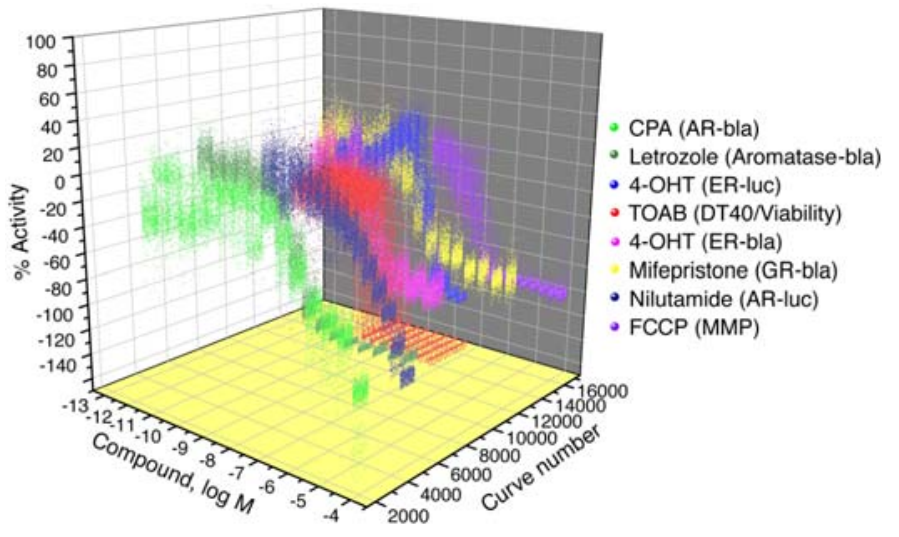

(b)

Notes: Ahr: aryl hydrocarbon receptor: AR: androgen receptor. ATAD5: ATPase family, AAA domain containing 5. ER: estrogen receptor. GR: glucocorticoid receptor. PPAR $\gamma$ : peroxisome proliferator-activated receptor gamma. TR: thyroid hormone receptor. T3: triiodothyronine. CPA: cyproterone acetate. FCCP: trifluorocarbonylcyanide phenylhydrazone. MMP: mitochondrial membrane potential. 4-OHT: 4-hydroxy tamoxifen. TOAB: tetraoctyl ammonium bromide. 
Tox21/NCGC uses qHTS assays in a 1,536-well plate format on a robotic system to enable the profiling of the Tox $2110 \mathrm{~K}$ compound collection. The 1,536-well plates only require 3-6 $\mu \mathrm{l}$ of assay volume per well. The first four columns of the 1,536-well plate containing control wells, including concentration response curves of a positive control compound in each screening assay (Figure 1), are used to normalise the data and assess the assay performance. The remaining 1,408 wells are used to simultaneously measure biological responses of test compounds at a single concentration in the same plate. Importantly, compounds are placed in different locations in three sets of compound plates to minimise interference from factors including uneven illumination or unequal dispensing volumes. In this manner, a given compound is assayed as three independent dilution series. The qHTS screens are conducted on a robotic platform containing four components: cell incubators and compound storage, liquid handling equipment, detectors for assay readouts, and software-controlled robotic arms (Attene-Ramos et al., 2013c). Prior to each Tox 21 10K qHTS screen, the candidate assay is validated with the online robotic system using a Library of 1,280 Pharmacologically Active Compounds $\left(\mathrm{LOPAC}^{1,280}\right.$ ) plus 88 Tox 21 compounds plated as duplicates in the $10 \mathrm{~K}$ library in three independent repeats. The online screens of the Tox $2110 \mathrm{~K}$ compound collection are assayed at 15 concentrations over 4 logarithmic units to yield more than 450 plates per screen.

Gross assay performance is assessed initially using quality metrics including $\mathrm{CV}$, $\mathrm{S} / \mathrm{B}$, and $\mathrm{Z}$ ' factor from each plate and also visually during the execution of the primary screen. 'Failed plates' identified by abnormally poor values are inspected visually and, if necessary, repeated as entire concentration-response curves. Assay data of good quality are subject to further processing, curation, and analysis. Compound concentration response data are first normalised to positive and negative controls in every plate and corrected using the DMSO control plates as previously described (Huang et al., 2011b; Southall et al., 2009). Concentration-response titration points for each compound are fitted to a four-parameter Hill equation (Hill, 1910) yielding concentrations of half-maximal activity $\left(\mathrm{AC}_{50}\right)$ and maximal response (efficacy) values (Wang et al., 2010). Compounds are classified into different activity categories (curve class 1-4) according to the type of concentration-response curve observed (Huang et al., 2011b; Inglese et al., 2006). Curves are then manually curated to correct for any curve fitting anomalies. The 'clean' fitting results from the triplicate runs as well as the Tox21-88 duplicated compounds are assessed for activity reproducibility to determine the final assay performance. As soon as the initial data parsing and assessment at the NCGC/NCATS are complete, the concentration response data, the curve fitting results, the raw plate reads, assay conditions, and sample mapping information are shared with the Tox 21 partners through a suite of databases and software tools custom built by the NCGC/NCATS for the Tox 21 program (http://tripod.nih.gov/tox) in which the data are further scrutinised for quality and utility. The data are then released to the public domain in a number of public databases including PubChem (http://pubchem.ncbi.nlm. nih.gov/), CEBS (http://tools.niehs.nih.gov/cebs3/ui/; Waters et al., 2008) and ACToR (http://actor.epa.gov/actor/faces/ACToRHome.jsp; Judson et al., 2008). 


\section{Validated qHTS assays for compound profiling}

A battery of cell-based assays has been developed and validated in a 1,536-well format at the NCGC/NCATS, some of which have been used to profile the Tox $2110 \mathrm{~K}$ compound collection (Huang et al., 2014; Hsu et al., 2014; Attene-Ramos et al., 2015). The majority of assays were evaluated using various compound libraries including the LOPAC, EPA, NTP, or NPC, and summarised in several reviews regarding the Tox 21 phase 1 screening (Shukla et al., 2010). These assays can be categorised into phenotypic, target-specific (e.g., nuclear receptors), or pathway-based assays (Table 1).

Table 1 List of NCGC toxicity-related assays

\begin{tabular}{|c|c|c|c|}
\hline Assay name & Readout & Description & Reference \\
\hline Cell viability & Bioluminescence & Intracellular ATP levels & $\begin{array}{c}\text { Xia et al. (2008), } \\
\text { Moeller et al. (2012), } \\
\text { Lock et al. (2012) and } \\
\text { Abdo et al. (2015) }\end{array}$ \\
\hline Apoptosis & Chemiluminescence & Caspase $3 / 7$ activity & $\begin{array}{l}\text { Huang et al. (2008) and } \\
\text { Lock et al. (2012) }\end{array}$ \\
\hline \multirow{2}{*}{$\begin{array}{l}\text { Membrane } \\
\text { integrity }\end{array}$} & Chemiluminescence & Protease release & \multirow[t]{2}{*}{ Cho et al. (2008) } \\
\hline & Fluorescence intensity & LDH release & \\
\hline \multirow[t]{4}{*}{$\begin{array}{l}\text { DNA damage/ } \\
\text { epigenetics }\end{array}$} & Fluorescence intensity & $\begin{array}{l}\text { Micronucleus, locus } \\
\text { derepression }\end{array}$ & \multirow{4}{*}{$\begin{array}{l}\text { Johnson et al. (2008), } \\
\text { Yamamoto et al. (2011), } \\
\text { Nishihara et al. (2016), } \\
\text { Fox et al. (2012) and } \\
\text { Hsu et al. (2016b) }\end{array}$} \\
\hline & Chemiluminsecence & $\begin{array}{l}\text { DNA damage, } \\
\text { HDAC activity }\end{array}$ & \\
\hline & Bioluminescence & ATAD5 production & \\
\hline & HTRF & H2AX phosphorylation & \\
\hline $\begin{array}{l}\text { Mitochondrial } \\
\text { toxicity }\end{array}$ & $\begin{array}{c}\text { Fluorescence intensity } \\
\text { (HTS and HCS } \\
\text { formats) }\end{array}$ & $\begin{array}{l}\text { Depolarisation of } \\
\text { mitochondrial membrane } \\
\text { potential }\end{array}$ & $\begin{array}{l}\text { Sakamuru et al. (2012) } \\
\text { and Attene-Ramos et al. } \\
(2013 \mathrm{~b}, 2015)\end{array}$ \\
\hline
\end{tabular}

Notes: FRET: fluorescence resonance energy transfer. HDAC: histone deacetylase. HTRF: homogeneous time resolved fluorescence. HCS: high content screening. HTS: high-throughput screening. TR-FRET: time resolved fluorescence resonance energy transfer. AhR: aryl hydrocarbon receptor. AP-1: activator protein 1. AR: androgen receptor. ARE: antioxidant response element. ATAD5: ATPase family AAA domain-containing protein 5. ATP: adenosine triphosphate. cAMP: cyclic adenosine monophosphate. CAR: constitutive androstane receptor. CRE: cAMP response element. CYP: cytochrome P450. ERa: estrogen receptor alpha. ESRE: endoplasmic reticulum stress response element. FXR: farnesoid X receptor. GPCR: G-protein coupled receptor. GR: glucocorticoid receptor. H2AX: H2A histone family, member X. hERG: human ether-à-go-go-related gene. HIF-1 $\alpha$. hypoxia inducible factor 1 alpha. HSE: heat shock element. Hsp70 and Hsp90: heat shock protein 70 and 90. IL-8: interleukin-8. LDH: lactate dehydrogenase. IP: inositol phosphate. LXR: liver X receptor. NF-kB: nuclear factor kappa-B. PDE: phosphodiesterase. PPAR $\delta$ and PPAR $\gamma$ : peroxisome proliferator-activated receptor delta and gamma. PXR: pregnane X receptor. RAR: retinoic acid receptor. ROR $\gamma$ : RAR-related orphan receptor gamma. RXR $\alpha$ : retinoid X receptor alpha. SIE: sis-inducible element. TNF- $\alpha$. tumour necrosis factor alpha. TR $\alpha$ and $\mathrm{TR} \beta$ : thyroid hormone receptor alpha and beta. VDR: vitamin $\mathrm{D}$ receptor. 
Table 1 List of NCGC toxicity-related assays (continued)

\begin{tabular}{|c|c|c|c|}
\hline Assay name & Readout & Description & Reference \\
\hline Phospholipidosis & $\begin{array}{c}\text { Fluorescence intensity } \\
\text { (HTS and HCS } \\
\text { formats) }\end{array}$ & $\begin{array}{c}\text { Intracellular } \\
\text { phospholipids }\end{array}$ & Shahane et al. (2014) \\
\hline \multirow{3}{*}{$\begin{array}{l}\text { Ion channel and } \\
\text { GPCR signalling }\end{array}$} & Fluorescence intensity & hERG activity & \multirow{3}{*}{$\begin{array}{l}\text { Titus et al. }(2009,2008 \mathrm{a} \text {, } \\
\text { 2008b), Xia et al. } \\
(2011 \mathrm{a}, 2011 \mathrm{~b}) \text {, Long } \\
\text { et al. }(2013) \text { and Liu } \\
\text { et al. }(2010,2008)\end{array}$} \\
\hline & TR-FRET & $\begin{array}{c}\text { Calcium influx (GPCR or } \\
\text { PDE activity) }\end{array}$ & \\
\hline & $\begin{array}{l}\text { HTRF, Fluorescence } \\
\text { intensity }\end{array}$ & $\begin{array}{l}\text { IP production (GPCR) } \\
\text { cAMP production }\end{array}$ & \\
\hline \multirow{2}{*}{$\begin{array}{l}\text { Cytokine } \\
\text { secretion }\end{array}$} & HTRF & IL- 8, TNF- $\alpha$ & \multirow[t]{2}{*}{ Leister et al. (2011) } \\
\hline & AlphaLISA & TNF- $\alpha$ & \\
\hline CYP induction & $\begin{array}{l}\text { Chemiluminescence, } \\
\text { bioluminescence }\end{array}$ & $\begin{array}{l}\text { Activity of CYP1A2, } \\
\text { CYP2C9, CYP2C19, } \\
\text { CYP2D6, or CYP3A4 }\end{array}$ & $\begin{array}{l}\text { Veith et al. (2009) and } \\
\text { Shukla et al. (2011) }\end{array}$ \\
\hline \multirow[t]{3}{*}{$\begin{array}{l}\text { Nuclear receptor } \\
\text { signalling }\end{array}$} & $\begin{array}{c}\beta \text {-lactamase coupled } \\
\text { FRET }\end{array}$ & $\begin{array}{c}\text { Transactivation of a } \\
\beta \text {-lactamase reporter gene } \\
\text { by AR, ER } \alpha, \text { FXR, GR, } \\
\text { LXR, PPAR } \delta \text {, PPAR } \gamma, \\
\text { RXR } \alpha, \text { TR } \beta, \text { VDR, or } \\
\text { ROR } \gamma\end{array}$ & $\begin{array}{l}\text { Judson et al. (2010a, } \\
\text { 2010b), Huang et al. } \\
\text { (2011b, 2014), Teng et } \\
\text { al. (2013), Rotroff et al. } \\
\text { (2013) and Hsu et al. } \\
\text { (2014) }\end{array}$ \\
\hline & Bioluminescence & $\begin{array}{c}\text { Transactivation of a } \\
\text { luciferase reporter gene by } \\
\text { PXR, CAR, AR, ER } \alpha, \\
\text { TR, AhR, or aromatase }\end{array}$ & $\begin{array}{l}\text { Shukla et al. (2011), } \\
\text { Lynch et al. (2013), } \\
\text { Chen et al. (2014), } \\
\text { Freitas et al. (2014) and } \\
\text { Chen et al. (2015) }\end{array}$ \\
\hline & TR-FRET & $\begin{array}{c}\text { Ligand binding and } \\
\text { coactivator recruitment to } \\
\mathrm{ER} \alpha, \operatorname{FXR}, \operatorname{PPAR} \gamma, \operatorname{PXR}, \\
\operatorname{TR} \alpha, \text { or } \operatorname{TR} \beta\end{array}$ & $\begin{array}{l}\text { Shukla et al. (2009, } \\
\text { 2011) }\end{array}$ \\
\hline
\end{tabular}

Notes: FRET: fluorescence resonance energy transfer. HDAC: histone deacetylase. HTRF: homogeneous time resolved fluorescence. HCS: high content screening. HTS: high-throughput screening. TR-FRET: time resolved fluorescence resonance energy transfer. AhR: aryl hydrocarbon receptor. AP-1: activator protein 1. AR: androgen receptor. ARE: antioxidant response element. ATAD5: ATPase family AAA domain-containing protein 5. ATP: adenosine triphosphate. cAMP: cyclic adenosine monophosphate. CAR: constitutive androstane receptor. CRE: cAMP response element. CYP: cytochrome P450. ERa: estrogen receptor alpha. ESRE: endoplasmic reticulum stress response element. FXR: farnesoid $\mathrm{X}$ receptor. GPCR: G-protein coupled receptor. GR: glucocorticoid receptor. H2AX: H2A histone family, member X. hERG: human ether-à-go-go-related gene. HIF-1 $\alpha$. hypoxia inducible factor 1 alpha. HSE: heat shock element. Hsp70 and Hsp90: heat shock protein 70 and 90. IL-8: interleukin-8. LDH: lactate dehydrogenase. IP: inositol phosphate. LXR: liver X receptor. NF-kB: nuclear factor kappa-B. PDE: phosphodiesterase. PPAR $\delta$ and PPAR $\gamma$ : peroxisome proliferator-activated receptor delta and gamma. PXR: pregnane $\mathrm{X}$ receptor. RAR: retinoic acid receptor. ROR $\gamma$ : RAR-related orphan receptor gamma. $\mathrm{RXR} \alpha$ : retinoid $\mathrm{X}$ receptor alpha. SIE: sis-inducible element. TNF- $\alpha$. tumour necrosis factor alpha. TR $\alpha$ and $\mathrm{TR} \beta$ : thyroid hormone receptor alpha and beta. VDR: vitamin D receptor. 
Table 1 List of NCGC toxicity-related assays (continued)

\begin{tabular}{|c|c|c|c|}
\hline Assay name & Readout & Description & Reference \\
\hline \multirow[t]{3}{*}{$\begin{array}{l}\text { Nuclear receptor } \\
\text { signalling }\end{array}$} & $\begin{array}{l}\text { Fluorescence } \\
\text { polarisation }\end{array}$ & Ligand binding to $\mathrm{TR} \beta$ & Johnson et al. (2011) \\
\hline & $\begin{array}{l}\text { Fluorescence intensity } \\
\text { (HCS) }\end{array}$ & $\begin{array}{c}\text { Nuclear translocation of } \\
\text { AR or ER }\end{array}$ & Teng et al. (2013) \\
\hline & $\begin{array}{l}\text { Enzyme fragment } \\
\text { complementation- } \\
\text { coupled } \\
\text { chemiluminescence }\end{array}$ & $\begin{array}{c}\text { Nuclear translocation of } \\
\text { GR }\end{array}$ & Zhu et al. (2008) \\
\hline \multirow[t]{2}{*}{$\begin{array}{l}\text { Stress response } \\
\text { signalling }\end{array}$} & $\begin{array}{c}\beta \text {-lactamase coupled } \\
\text { FRET }\end{array}$ & $\begin{array}{l}\text { Transactivation of a } \\
\beta \text {-lactamase reporter gene } \\
\text { by AP-1, ARE, CRE, } \\
\text { HSE, HIF-1 } \alpha \text {, SIE, NF- } \\
\text { ผB, p53, or ESRE }\end{array}$ & $\begin{array}{l}\text { Xia et al. (2009a, 2009b, } \\
\text { 2009c, 2009d), Miller } \\
\text { et al. (2010), Shukla } \\
\text { et al. (2012), Hancock } \\
\text { et al. (2009), Johnson } \\
\text { et al. (2009), Bi et al. } \\
\text { (2015) and Hsu et al. } \\
\text { (2016a) }\end{array}$ \\
\hline & $\begin{array}{l}\text { Bioluminescence } \\
\text { AlphaScreen }\end{array}$ & 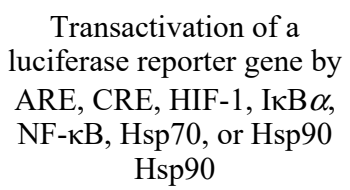 & $\begin{array}{l}\text { Shukla et al. (2012), Xia } \\
\text { et al. (2009c), Davis et } \\
\text { al. (2007), Miller et al. } \\
\text { (2010) and Hsu et al. } \\
\text { (2016a) }\end{array}$ \\
\hline
\end{tabular}

Notes: FRET: fluorescence resonance energy transfer. HDAC: histone deacetylase. HTRF: homogeneous time resolved fluorescence. HCS: high content screening. HTS: high-throughput screening. TR-FRET: time resolved fluorescence resonance energy transfer. AhR: aryl hydrocarbon receptor. AP-1: activator protein 1. AR: androgen receptor. ARE: antioxidant response element. ATAD5: ATPase family AAA domain-containing protein 5. ATP: adenosine triphosphate. cAMP: cyclic adenosine monophosphate. CAR: constitutive androstane receptor. CRE: cAMP response element. CYP: cytochrome P450. ERa: estrogen receptor alpha. ESRE: endoplasmic reticulum stress response element. FXR: farnesoid $\mathrm{X}$ receptor. GPCR: G-protein coupled receptor. GR: glucocorticoid receptor. H2AX: H2A histone family, member X. hERG: human ether-à-go-go-related gene. HIF-1 $\alpha$. hypoxia inducible factor 1 alpha. HSE: heat shock element. Hsp70 and Hsp90: heat shock protein 70 and 90 . IL-8: interleukin-8. LDH: lactate dehydrogenase. IP: inositol phosphate. LXR: liver X receptor. NF-kB: nuclear factor kappa-B. PDE: phosphodiesterase. PPAR $\delta$ and PPAR $\gamma$ : peroxisome proliferator-activated receptor delta and gamma. PXR: pregnane X receptor. RAR: retinoic acid receptor. ROR $\gamma$ : RAR-related orphan receptor gamma. RXR $\alpha$ : retinoid X receptor alpha. SIE: sis-inducible element. TNF- $\alpha$. tumour necrosis factor alpha. TR $\alpha$ and $\operatorname{TR} \beta$ : thyroid hormone receptor alpha and beta. VDR: vitamin $\mathrm{D}$ receptor.

\section{Phenotypic assays}

Phenotypic assays measure phenotypic changes of cells upon compound treatment. Available phenotypic assays include cell death, DNA damage, membrane integrity, mitochondrial toxicity, and accumulation of biomolecules (Figure 2). The viability or cytotoxicity assays used in the Tox21/NCGC screening measure intracellular ATP production or membrane integrity by quantifying activity of protease or lactate 
dehydrogenase $(\mathrm{LDH})$ released from the damaged cells with fluorescence or luminescence readouts (Cho et al., 2008; Xia et al., 2008; Huang et al., 2008; Miller et al., 2010). These assays can be multiplexed with other assays including nuclear receptor- and pathway-based assays in the same well, which greatly reduce screening time and reagent usage, as well as provide a more information-rich dataset. Recent studies compared chemical-induced cytotoxicity on 81 and later 1,036 human lymphoblast cell lines of differential genetic backgrounds and populations (Lock et al., 2012; Abdo et al., 2015). The authors found a good correlation between toxicity phenotypes and genotypes, demonstrating the feasibility of using genomic data as predictors for compound toxicity. Another exciting breakthrough in hepatotoxicity testing is the use of human cryopreserved hepatocytes in 1,536-well plates (Moeller et al., 2012) because the majority of liver-derived cancer cell lines lack intracellular metabolic activity. For example, a human hepatocellular carcinoma cell line, HepG2, though commonly used to screen for cytotoxic compounds, lacks most phase 1 and phase 2 metabolic enzymes and transporters. Therefore, these human cryopreserved plateable hepatocytes could serve as a plausible alternative for hepatotoxicity testing that may generate data with better correlation with in vivo experiments. However, compared to HepG2 cells, human hepatocytes are much more expensive and difficult to get sufficient cell numbers for large scale screening. Recently, assay applications based on HepaRG, terminally differentiated hepatic cells derived from a human hepatocellular carcinoma cell line, have gained increasing interests due to its high metabolic activities (Kanebratt and Andersson, 2008). The utility of this cell line for HTS in a 1,536-well format is still under investigation. Cell viability assays have also been used to evaluate the effect of DNA-damage inducing compounds on a group of isogenic DNA repair-deficient chicken DT40 cell lines (Yamamoto et al., 2011; Nishihara et al., 2016). Differential cytotoxicity patterns were observed in these cell lines depending on the type of DNA-damage inducing compounds, making them good research tools for identifying genotoxic compounds and associated mechanisms. Another DNA damage assay, measuring ATAD5 induction, has been developed and validated (Fox et al., 2012). ATAD5 is the human homolog of yeast enhanced level of genome instability gene 1 (ELG1) that retains proliferating cell nuclear antigen to regulate the lifecycle of DNA replication. The authors took advantage of the fact that ATAD5 proteins become stabilised in response to DNA damage and designed an ATAD5-luciferase reporter gene system (ATAD5-luc) that measures changes of luminescence signal to reflect DNA damage. Several genotoxic and non-mutagenic antioxidants were identified as potential chemotherapeutic agents after the screening and follow up studies. One notable observation was that the current genotoxicity assays have low hit rates (Knight et al., 2009), most likely due to insufficient metabolic activity across the sensor cell lines.

Cell-permeable fluorescent dyes not only report signalling events as whole-cell fluorescence changes but also capture spatio-temporal dynamics of a specific signalling event. For instance, a mitochondrial membrane potential (MMP) assay can detect mitochondrial dysfunction, an important cause of compound-induced heptatoxicity and cardiotoxicity. To identify environmental chemicals that disrupt MMP, assay optimisation, including dye selection, and robotic online validation of the MMP assay were conducted prior to the robotic online screen. Mito-MPS, a fluorescent lipophilic cationic dye, has been shown to sense MMP change in HepG2 cells with or without compound treatment and is superior to other cationic dyes such as JC-1, rhodamine 123 , and tetramethylrhodamine (Sakamuru et al., 2012). In response to mitochondrial 
depolarisation, the ratio of the mitochondrial red fluorescent aggregates to the cytosolic green fluorescent monomeric form decreases. The ratiometric (red/green) readout in fluorescence intensity can be measured by commonly used plate readers. The change of the red and green fluorescence in the assay can also be visualised and quantified by high-content imaging based readers including the ImageXpress Micro System. After screening the LOPAC and NTP collections, several compound clusters that contained tyrphostin, 3'-substituted indolone analogues and flavonoids were identified (Sakamuru et al., 2012; Attene-Ramos, et al., 2013b). This MMP assay using Mito-MPS dye has been validated with the online robotic system using the LOPAC plus 88 Tox21 compounds plated as replicates in triplicate runs [Figure 3(a)]. The MMP assay online validation performance satisfied the HTS assay requirements [Figure 3(b)] with a low mismatch rate under $1 \%$ [Figure 3(c)]. This assay has been applied to profile the Tox 21 10K compound library for mitochondrial toxicity (Attene-Ramos et al., 2015; Potera, 2015). Another recently reported phenotypic assay workable in a high-throughput and high content format is a cell-based assay using the LipidTOX Red reagent to detect compound induced phospholipidosis (PLD), a phenotype of abnormal accumulation of intracellular phospholipids (Shahane et al., 2014). This cell-based PLD assay has been optimised in a 1,536-well format and validated by screening a LOPAC library in HepG2 cells. A group of known PLD inducers including propranolol and amiodarone and several novel PLD inducers, such as NAN-190, ebastine, GR127935, and cis-(Z)-fluphentixol, were identified and further confirmed to induce PLD using electron microscopy (EM). In general, the HTS capability of such assays allows rapid screening of large chemical libraries, and the HCS capability is particularly useful for compound confirmation as well as follow-up studies.

Figure 2 (a) Cytotoxicity related assays measure membrane integrity, ATP content, caspase 3/7 activity, and release of proteases or LDH (b) Mitochondrial toxicity is measured by membrane potential-sensing dyes that exist as green fluorescent monomers in the cytoplasm and red fluorescent J-aggregates at the electron-rich mitochondria
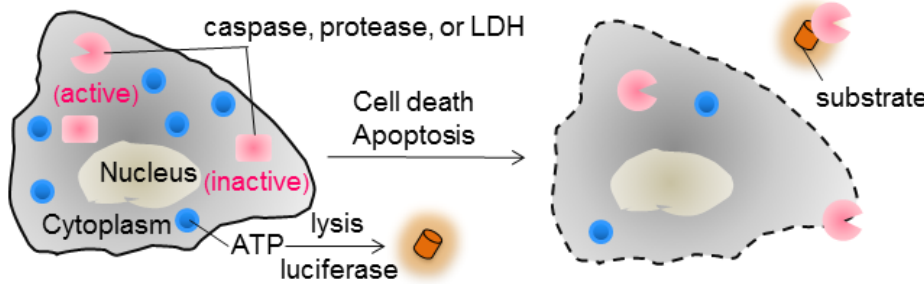

(a)

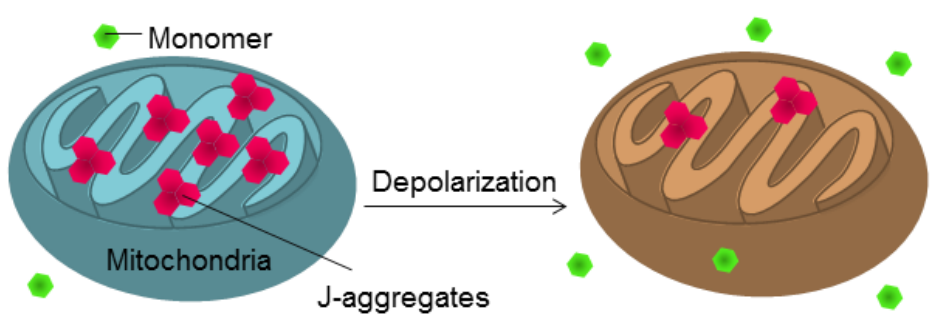

(b) 
Figure 3 Online validation of a MMP assay, (a) concentration-response curves of the positive control carbonyl cyanide 4-(trifluoromethoxy) phenylhydrazone (FCCP) and all tested LOPAC compounds in the MMP assay in triplicates (different colours) (b) screen statistics of the MMP assay (c) screening data reproducibility of the MMP assay

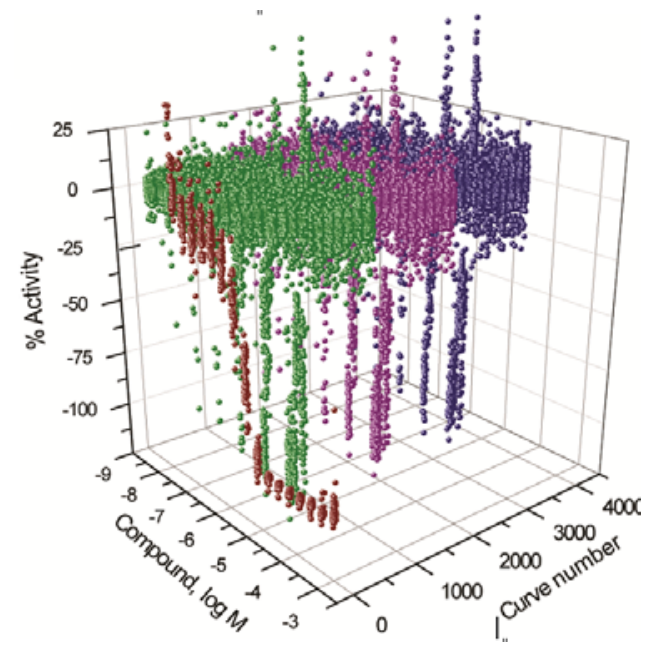

(a)

\begin{tabular}{|c|c|}
\hline MMP Assay & Mean \pm SD \\
\hline S/B & $9.4 \pm 0.2$ \\
\hline CV (\%) & $7.9 \pm 0.4$ \\
\hline Z' factor $^{\prime}$ & $0.77 \pm 0.01$ \\
\hline
\end{tabular}

(b)

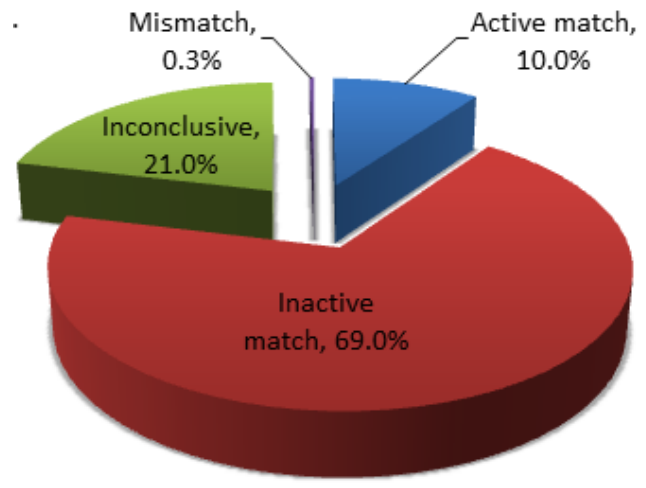

(c)

Notes: S/B: signal to background ratios. CV: coefficient of variation. 


\section{Target-specific assays}

Abnormal secretion and transport of signalling molecules are indicators of potential toxicity of a given compound. For example, the cytokine tumour necrosis factor alpha $(\mathrm{TNF}-\alpha)$ has been found to mediate effect of the environmental estrogens on apoptosis of MCF-7 breast cancer cells (Burow et al., 1999). Two homogeneous cell-based TNF- $\alpha$ assays have been developed and optimised in a 1,536-well plate format using homogeneous time resolved fluorescence (HTRF) and AlphaLISA immunoassay technologies. Leister et al. (2011) further validated these assays by conducting a LOPAC screen. The HTRF-based TNF- $\alpha$ assay requires labeling anti-TNF- $\alpha$ antibodies with HTRF donor or acceptor fluorophores. Newly secreted human TNF- $\alpha$ molecules bring the two types of dye-labelled antibodies in proximity, resulting in fluorescence resonance energy transfer (FRET) from the HTRF donor to the HTRF acceptor. The AlphaLISAbased TNF- $\alpha$ assay shares a similar assay design but with more complex components. The donor moiety consists of a biotinylated anti-TNF- $\alpha$ donor and a streptavidin-coated donor bead. The counterpart is a TNF- $\alpha$ antibody-coated acceptor bead. In the presence of TNF- $\alpha$, the donor and the acceptor beads are at a close distance $(<200 \mathrm{~nm})$, allowing laser-excited singlet oxygen released from the donor bead to travel to the nearby acceptor beads and produce signals. The two TNF- $\alpha$ assays yielded similar profiles of potency and efficacy values of cherry-picked compounds that inhibit TNF- $\alpha$ secretion. A similar cell-based HTRF assay used dye-labelled inositol-1-phosphate (IP1) tracers and IP1-specific antibodies to measures IP1 (Liu et al., 2008), a signalling molecule downstream of G-protein coupled receptors (GPCRs). GPCRs sense extracellular stimuli and transmit signals to the cyclic adenosine monophosphate (cAMP) signalling pathway or the phosphatidylinositol (PI) signalling pathway. GPCR profiling is important because many drugs raise safety concerns through off-target effects on GPCRs (Christopoulos et al., 2004). Several cell-based assays that measure GPCR signalling have been optimised in 1,536-well formats to probe cyclic nucleotide phosphodiesterases-mediated cAMP conversion (Titus et al., 2008b), G-protein coupled cAMP production (Xia et al., 2011a), Gq-protein coupled receptor-mediated calcium flux (Liu et al., 2010), and thyroid-stimulating hormone (TSH) receptor-mediated cAMP production (Titus et al., 2008a). A common cause of drug-induced cardiotoxicity is the inhibition of human ether-a-go-go-related gene (hERG) channel. To identify hERG inhibitors, Titus et al. (2009) developed a homogeneous cell-based hERG assay that measures the flux of fluorogenic indicators of thallium ions across the hERG channel. Quaternary ammonium salts such as tetra-n-octylammonium bromide (TOAB) and benzethonium chloride were later confirmed to be open-channel blockers of hERG that may induce long QT syndrome (LQTS) and cardiac arrhythmia (Xia et al., 2011b; Long et al., 2013).

Cytochrome P450 (CYP) enzymes are key players in xenobiotic metabolism that convert xenobiotic substances into metabolites with toxicity profiles different than the parent compounds (Coon, 2005). Veith et al. (2009) validated a group of enzyme-based bioluminescent CYP assays in a 1,536-well format and characterised compound effects on a panel of CYP enzymes comprising of CYP1A2, CYP2C9, CYP2C19, CYP2D6, and CYP3A4 using luminogenic substrates of individual CYP enzymes. The authors screened over $17 \mathrm{~K}$ bioactive compounds and approved drugs and conducted structure-activity relationship (SAR) analysis of active compounds. They observed that greater extent of bioactive compounds than approved drugs inhibited all five CYP enzymes, probably 
owing to the fact that most clinically-used drugs were optimised to avoid CYP activity during the drug development stage.

\section{$7 \quad$ Nuclear receptor assays}

Several nuclear receptor signalling pathways have been found to be the direct targets of highly hazardous substances such as endocrine disruptors (Casals-Casas and Desvergne, 2011). Endocrine signalling pathways including the androgen receptor (AR) and estrogen receptors (ERs) have been linked to reproductive and developmental defects. Abnormal activity of retinoic X receptors (RXRs) and thyroid hormone receptors (TRs) has diverse effects on the central nervous system (CNS), circadian rhythm, and metabolism (Yang, 2010). In addition to RXRs and TRs, the glucocorticoid receptor (GR) and the peroxisome proliferator-activated receptors (PPARs) govern energy homeostasis and lipid metabolism (Francis et al., 2003). The farnesoid X receptor (FXR), the pregnane X receptor (PXR), the liver X receptor (LXR), the constitutive androstane receptor (CAR), and the vitamin D receptor (VDR) are likely to mediate toxicity or protect cells from toxic substances due to their roles in homeostasis of bile acids and xenobiotic metabolism (Francis et al., 2003). Owing to the toxicological and pharmacological impacts of these nuclear receptors, several biochemical and cell-based assays have been developed by academia and industry to measure the effects of compounds on receptor binding, receptor translocation, or transactivation of target genes by the corresponding nuclear receptor (Table 1). Many of these assays are also commercially available for routine testing. The cell-based nuclear receptor transactivation assays are commonly constructed using $\beta$-lactamase-dependent FRET (NR-bla) or luciferase (NR-luc) reporter gene technologies (Figure 4). NR-bla assays usually use the ligand binding domain (LBD) of the nuclear receptor of interest and generate a ratiometric response in fluorescence intensity. Many of NR-luc assays are based on a full length nuclear receptor and luminescence readout. During the Tox 21 phase 1 screening, a collection of approximately 2,800 compounds provided by both EPA and NTP were screened against a panel of NR-bla assays including AR, ER $\alpha$, FXR, GR, LXR $\beta$, PPAR $\gamma, \operatorname{PPAR} \delta, \operatorname{RXR} \alpha, \mathrm{TR} \beta$, and VDR in 1,536-well formats (Huang et al., 2011b). The agonist or antagonist response (activation/ inhibition phenotypes and $\mathrm{EC}_{50} / \mathrm{IC}_{50}$ ) of known positives generated by the NR-bla screens was consistent with literature, indicating the feasibility of these assays for biologically relevant studies. The study also revealed that many antagonists identified from the NRbla screening had $\mathrm{IC}_{50}$ values similar to those found in the viability assays, suggesting potential false positives due to cytotoxicity. Freitas et al. (2014) identified the structural classes of TR agonists and TR antagonists by screening the LOPAC and NTP compounds in a luciferase reporter gene-based TR transactivation assay in the qHTS format. Four out of the five identified TR antagonist-like compounds were later found to be cytotoxic, conferring the importance of incorporating cytotoxicity testing in primary screens. Therefore, cell viability counter-screens multiplexed with pathway/target-based screens have been incorporated into the Tox 21 phase 2 screening process. Some compounds such as polycyclic aromatic hydrocarbons (PAHs) and coumarin dyes are likely false positives in the NR-bla agonist screens owing to compound autofluorescence at the detection wavelengths of bla reporter signals. To overcome this, compounds from the Tox 21 compound library have been tested for their autofluorescence potential at multiple wavelengths that are commonly used in screening assays (Simeonov et al., 2008). To 
identify chemical classes specifically modulating FXR signalling, Hsu et al. (2014) developed a cross-comparison strategy that compares compound potency and efficacy in all available Tox21 NR-bla assays as well as an FXR coactivator assay. The results indicated that activation of FXR is highly ligand-selective and many FXR-environmental chemicals might indirectly inhibit FXR activity by altering intracellular trafficking or epigenetics regulation of FXR-related signalling molecules. Furthermore, orthogonal assays using different technologies are useful alternatives to rule out assay artifacts such as compound autofluorescence. For example, the cell-based ER-luc assay can be used to follow up on the positives identified from the ER-bla primary screen (Teng et al., 2013).

Figure 4 Both $\beta$-lactamase and luciferase reporter gene assays measure $\beta$-lactamase or luciferase production induced by nuclear receptors or transcription factors

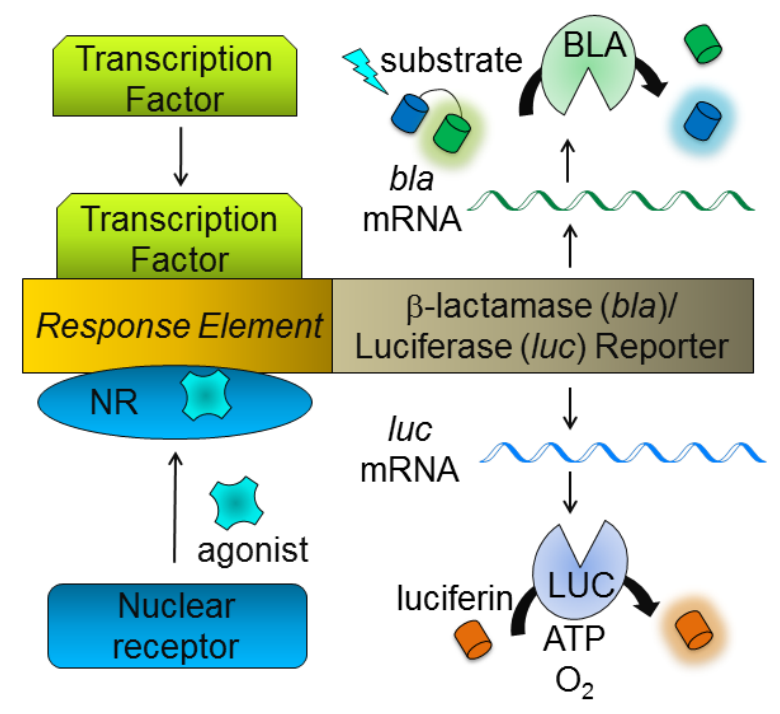

Notes: The $\beta$-lactamase activity is determined by a $\beta$-lactamase-sensitive FRET reaction, while the luciferase activity is measured by catalysing a reaction with luciferin to produce light.

Available assay technologies for nuclear receptor binding include AlphaScreen, fluorescence polarisation (FP), time-resolved fluorescence (TRF), and time-resolved FRET (TR-FRET). Johnson et al. (2011) identified inhibitors that block the binding between the human TR $\beta$-LBD and a dye-labelled peptide derived from its coactivator proteins using a FP-based receptor binding assay. Comparing the assay performance of AlphaScreen, TR-FRET, and TRF technologies for FXR-ligand binding assays, Glickman et al. (2002) concluded that the FXR AlphaScreen assay was the most sensitive in terms of detection limit and dynamic range, and the FXR TR-FRET assay had the least well-to-well variation. However, the FXR TRF assay requires multiple washing steps, making it less favourable for HTS. Recently, homogeneous and versatile TR-FRET-based nuclear receptor co-activator assays have been designed for a wide selection of nuclear receptors (Table 1) in which fluorescein-labelled ligands/coregulator peptides and Tb-labelled antibodies are used [Figure 5(a)]. In the TR-FRET PPAR $\gamma$ assays shown in Figures 5(b) and 5(c), GW1929, PPAR $\gamma$ agonist (Brown et al., 1999), stimulated coactivator recruitment and GW9662, PPAR $\gamma$ antagonist (Davies et al., 2001), inhibited 
coactivator recruitment in a dose-dependent manner. Shukla et al. (2009) screened over 80,000 compounds from various libraries for their ability to bind PXR using a homogeneous PXR TR-FRET assay containing fluorescein-labelled PXR ligands, GST-tagged PXR, and Tb-labelled anti-GST antibodies. The authors also took advantage of the qHTS in generating multiple concentration-response curves to probe for assay artefacts caused by compound autofluorescence, signal quenching, aggregate formation, or diffusion-enhanced FRET. In a related study, the PXR TR-FRET assay was applied to identify PXR agonists from the qHTS screen of human and rodent PXR-luc reporter gene assays (Shukla et al., 2011).

Figure 5 Nuclear receptor coactivator assay

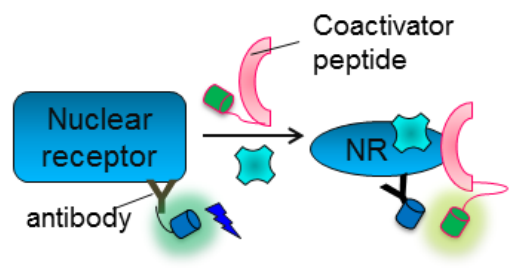

(a)

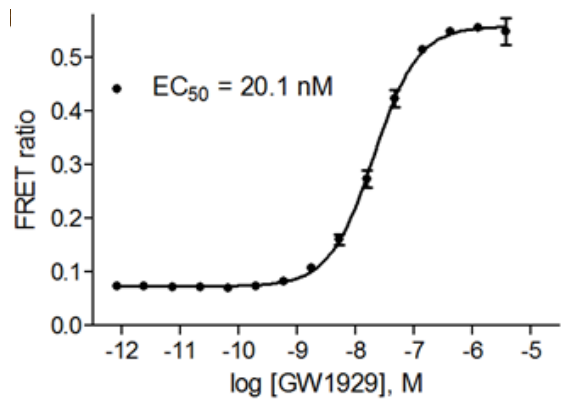

(b)

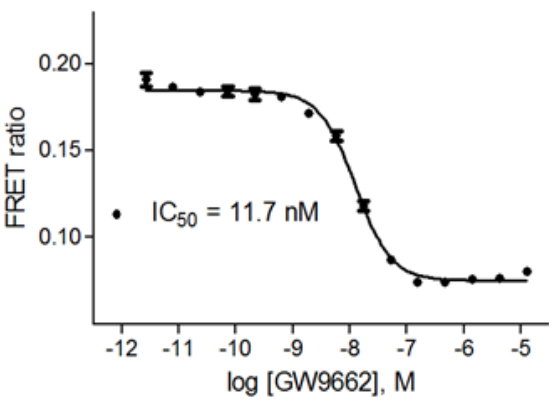

(c)

Notes: (a) TR-FRET nuclear receptor coactivator assay reports agonist binding and recruitment of a coactivator peptide. A long-lived donor fluorophore is covalently attached to an antibody binding to the nuclear receptor. The pairing acceptor fluorophore is labelled on the coactivator peptide in which ligand binding brings two fluorophores in proximity and results in altered FRET. The concentrationresponse curves of the TR-FRET PPAR $\gamma$ coactivator assay were measured in (b) agonist mode and (c) antagonist mode in a 1,536-well format. GW1929 and GW9662 are known synthetic agonist and antagonist of PPAR $\gamma$, respectively.

Nuclear receptor translocation is an important indicator of nuclear receptor function and can be measured in HTS and HCS platforms in order to study the mechanism of compound action. Environmental chemicals including polychlorinated biphenyls (PCBs), PAHs, and heavy metals have been shown to disrupt GR signalling and increase health risk (Odermatt et al., 2006). A cell-based $\beta$-galactosidase fragment complementation assay of GR translocation was validated in a 1,536-well format and applied to a qHTS screen (Zhu et al., 2008). The C-terminus of GR was fused to the enzyme donor (ED) fragment of $\beta$-galactosidase and the GR-ED fusion protein remains in the cytoplasm in the absence of agonist binding. Upon addition of a GR agonist, the activated GR-ED translocates to the nucleus and reconstitutes an active enzyme with the pairing enzyme 
acceptor (EA) acceptor fragment of $\beta$-galactosidase. The reconstituted $\beta$-galactosidase enzyme is capable of converting a chemiluminescent substrate to report on GR activity. To explore the mechanism of the AR activity of bisphenol A (BPA) in live cells, Teng et al. (2013) monitored the redistribution of AR and ER after treatment of BPA in sensor cell lines stably expressing AR-EGFP (enhanced green fluorescent protein) or ER $\alpha$ EGFP fusion protein. Upon activation, AR or ER translocates from the cytoplasm to the nucleus, thus nuclear receptor redistribution can be visualised and quantified on a high content imaging system. In the study, BPA was found to be an ER $\alpha$ agonist and an AR antagonist. The combination of nuclear receptor transcription, receptor binding and coactivator recruitment, and nuclear translocation assays provides informative insights to compound mechanism in a high-throughput manner.

\section{Pathway-based assays}

Pathway-based assays measure the activation or inhibition of compounds in a given signalling pathway. Selection of such assays requires prior knowledge of the toxicity outcomes as related to the pathway of interest. The $\beta$-lactamase (bla) reporter gene assay technology has been implemented to probe activity of several key intracellular signalling pathways. For example, the heat shock factor (HSF) pathway protects cells from proteostasis-related toxicity effects (Resenberger et al., 2012). A HeLa cell line was engineered to express the bla reporter gene under the control of HSF response elements (HSE) present in the promoter region of heat shock protein 70 (Hsp70). HSE-bla assays in 1,536-well formats have been developed and can be used to screen for modulators of the heat shock response signalling (Hancock et al., 2009). The HSE-bla assay exhibited robust assay performance including the response against known HSR inducers, 17-allylamino-17-demethoxygeldanamycin (17-AAG) and bortezomib, and HSR-specific RNAi oligos, thus the HSE-bla is a promising platform for cell-based HTS of HSR modulators. Potential inhibitors that disrupt Hsp90-cochaperone interaction were identified by a bead-based proximity AlphaScreen Hsp90 assay after screening over 76,000 compounds (Yi et al., 2009). Hsp70 cooperates with the cAMP-response element-binding (CREB) pathway to ameliorate polyglutamine-caused toxicity in fruit flies (Iijima-Ando et al., 2005). To identify CREB signalling enhancers, Xia et al. $(2009 \mathrm{c})$ validated a $\beta$-lactamase reporter gene assay for CREB (CREB-bla) signalling activity in a 1,536-well format, screened over 73,000 compounds, and identified a group of compounds that potentiated the CREB signalling pathway. Hsp90 regulates the stabilisation of hypoxia-inducible factor 1 alpha (HIF-1 $\alpha$ ), another key cytoprotector during hypoxia (Isaacs et al., 2002). A $\beta$-lactamase-based cellular assay of HIF-1 $\alpha$ transcription (HRE-bla) was optimised in a 1,536-well plate format and employed to identify compounds that induce HIF-1 $\alpha$ activity (Xia et al., 2009d) or inhibit HIF-1 $\alpha$ signalling pathway (Xia et al., 2009a).

The combined use of different assay platforms can provide additional insights into the mechanism of compound action. For example, the 1,408 compounds in the NTP collection were profiled for their ability to induce the antioxidant response element (ARE) signalling pathway using a cell-based ARE-driven $\beta$-lactamase reporter gene assay (ARE-bla) in HepG2 cells, followed by compound confirmation with a cell-based ARE-driven luciferase reporter gene assay (ARE-luc) (Shukla et al., 2012). A similar 
approach was adapted to identify nuclear factor-kappa B (NF-kB) inhibitors from the NPC library (Miller et al., 2010). The NF-kB bla assay showed increased reporter activity when stimulated with tumor necrosis factor alpha (TNF- $\alpha$ ), a known activator of the NF- $\mathrm{KB}$ pathway, and decreased TNF- $\alpha$-induced NF- $\mathrm{\kappa B}$ transactivation upon treatment of MG132 a known proteasome inhibitor. To deconvolute the compound action in the $\mathrm{NF}-\mathrm{\kappa B}$ signal transduction cascade, several follow-up assays including I $\mathrm{k}-\mathrm{B} \alpha$ phosphorylation, LDH release, MMP, and caspase 3/7 activity were used to test the $\mathrm{NF}-\kappa \mathrm{B}$ inhibitors identified from the primary screening. The Iк-B $\alpha$ phosphorylation assay was based on TR-FRET between intracellular GFP-tagged Iк-B $\alpha$ and Tb-labelled

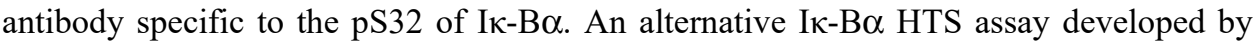
Davis et al measures I $\kappa-B \alpha$ stabilisation by quantifying emission ratios from a red luciferase and an Iк-B $\alpha$-responsive green luciferase (Davis et al., 2007). In this study, the IK-B $\alpha$ ratiometric sensor engineered into a patient-derived non-Hodgkin's lymphoma cell line was used to screen for NF-kB inhibitors. As HTS assays become applicable to high-density qHTS formats and automation, the rich datasets produced can be used to study the mechanism of compound action and SAR of a large number of compounds in a high-throughput manner.

\section{Predictive modelling}

The high quality concentration response data generated on a wide spectrum of pathways and phenotypic toxicity endpoints provide a valuable resource for predictive toxicity modelling. These data not only can serve as in vitro signatures to predict in vivo toxicity endpoints (Sipes et al., 2011; Martin et al., 2011) and to prioritise chemicals for more in depth toxicity testing (Judson et al., 2010a) that help to fulfil the goals of the Tox21 program, but also can provide rich training data sets for the QSAR (quantitative structureactivity relationship) modelling community to build more robust models (Huang et al., 2009; Sun et al., 2012c). QSAR models were developed for two of the Tox21 assays (Sun et al., 2012a, 2012b), with rigorous performance evaluation of all models using receiver operating characteristic curves (Schoonjans et al., 1996). Models were built based on the qHTS data generated on a library of drug-like molecules for their activity against five human cytochrome P450 (CYP) isozymes, CYP1A2, CYP2C9, CYP3A4, CYP2C19, CYP2D6 (Sun et al., 2011; Veith et al., 2009). These models were then applied to predict the CYP profiles of Tox21 phase 1 library of environmental chemicals and the predictions compared with the experimental results obtained for the same chemicals (Sun et al., 2012b). Within the test compound set, the environmental chemicals largely fall outside of the applicability domain (AD) of the models built with drug-like molecules. The predictions for three of the isozymes achieved $>80 \%$ accuracies. The two models with lower predictive power were improved by rebalancing the training data. The atom typing-based structure descriptors (Sun, 2004) enhanced the coverage of the models' AD and enabled these models to make accurate predictions on the CYP activity of environmental chemicals that are dissimilar to drug-like molecules. This atom typingbased approach was also applied to build models for drug-induced PLD (Sun et al., 2012a). In this exercise, one-third of the qHTS data from screening a bioactive collection including the NPC, LOPAC and Tocris compound libraries was used as the training set to build the model and two-thirds of the data were held out to test the model performance. 
One of the lessons learned from this exercise is that increasing the structure diversity of a training set is more important than increasing its size for improving the predictive power of a model. Using one-third of the data randomly selected to train the model to ensure structure diversity, the consensus model obtained $90 \%$ accuracy in predicting the remaining two-thirds of data. These results reassure the decision of expanding the Tox 21 library to the $10 \mathrm{~K}$ collection with more diverse chemicals that can serve as a solid foundation for better understanding of SARs and better models.

The prediction models built on HTS assay data may be useful for regulatory scientists to assess chemical toxicity. The EPA Endocrine Disruptor Screening Program (EDSP) and the NTP Interagency Center for the Evaluation of Alternative Toxicological Methods (NICEATM) have been applying the Tox21 datasets to build QSAR prediction models and in vitro-in vivo correlation analysis (Zang et al., 2013; Chang et al., 2015). For instance, an ER Interaction Score model, generated based on 13 in vitro ER HTS assay data from 1,814 ToxCast/Tox21 chemicals, was utilised to predict in vivo uterotrophic activity of 45 chemicals, achieving 91\% sensitivity and 65\% specificity (Rotroff et al., 2013). Industrial toxicologists also started to use the ToxCast and Tox 21 data as well as human exposure estimates to rank potential endocrine disruptors (Becker et al., 2015). Chang et al. (2015) at NICEATM conducted an in vitro-to-in vivo extrapolation (IVIVE) study of 230 potentially ER-active environmental chemicals tested in Tox $2110 \mathrm{~K}$ screening, suggesting the need of compound pharmacokinetics in prioritising chemicals for further endocrine-related tests. Additionally, Politi et al. (2014) demonstrated the usefulness of HTS data in confirming results generated from virtual screening for TR ligands. To supplement current toxicity assessment methods with computational modelling, NCATS launched a crowdsource challenge in 2014 that asked the participants to build computational models predictive of chemical toxicity (Huang et al., 2015). Data generated from 12 assays, including a panel of nuclear receptor assays and a panel of stress response pathway assays, on Tox $2110 \mathrm{~K}$ chemicals were provided as the training sets for the models. 378 models from 40 teams worldwide were received for final evaluation. All of the winning models displayed $>80 \%$ accuracy, with some exceeding $90 \%$ accuracy (Huang et al., 2015). The high quality of models served as a validation of the Tox 21 screening effort as the model quality is highly dependent on data quality. The winning models will become part of the Tox 21 program arsenal of tools that help researchers identify the chemicals that have the most potential for toxicity and prioritise them for further toxicological evaluation.

\section{Concluding remarks}

The Tox 21 program, a collaborative partnership of three US federal agencies, NIH, EPA, and FDA, integrates assay technology and informatics to enable rapid testing of hundreds of thousands of environmental chemicals and assessment of their potential adverse effect on human health. After the proof of principle study that validated and screened a battery of assays against approximately 2,800 environmental chemicals, the chemical collection was expanded to over $10 \mathrm{~K}$ compounds and the screens were conducted on the Tox 21 robotic system. During the Tox 21 phase 2 screening, a group of nuclear receptor assays including AhR, AR, ER $\alpha, \mathrm{FXR}, \mathrm{GR}, \operatorname{PPAR} \gamma, \operatorname{PPAR} \gamma, \mathrm{RXR} \alpha$, TR, and VDR (Table 1) has been used to profile the Tox $2110 \mathrm{~K}$ compounds. Both $\beta$-lactamase-based (e.g., ARbla, ER-bla) and luciferase-based (e.g., AR-luc, ER-luc) assays were employed in 
primary screens to decipher mechanisms of newly identified AR and ER agonists and antagonists (Huang et al., 2014). Modulators of FXR identified from Tox21 10K screening were prioritised by comparing compound activity across all the nuclear receptor assays (Hsu et al., 2014). The second screening focus area was a group of stress response pathway assays including $\mathrm{p} 53$, NF- $\mathrm{kB}, \mathrm{HIF}-1 \alpha, \mathrm{pH} 2 \mathrm{AX}$, activator protein 1 (AP-1), endoplasmic reticulum (ER) stress, MMP (Attene-Ramos et al., 2015), ARE/Nrf2 , heat shock response, DNA damage, and reactive oxygen species (ROS). Cell viability or cytotoxicity readouts multiplexed with the nuclear receptor or stress response assays were incorporated into the online screening to rule out the positive responses due to compound cytotoxicity. The actives identified from primary screening were prioritised for further in-depth toxicological investigation based on considerations such as compound potency, efficacy, SAR and environment production volume. The Tox 21 datasets generated from the screening were deposited into public databases and provide scientists with new resources for building predictive models for chemical toxicity.

To search for more biologically relevant assays for the Tox 21 program, the future assay battery will focus on developmental toxicology, epigenetics, and human diseases including mitochondrial disorders. Development and validation of metabolically active sensor cells including human primary cells and stem cell derived tissue-specific cells for HTS assays may provide better extrapolation of chemical toxicity to humans. Expansion of the current HTS/HCS assay battery, development of organotypic cultures, and advances in informatics and robotic technology will enhance the capacity of secondary and follow-up studies for further compound prioritisation. Compound clustering based on structural similarity, biological functions, and assay response will improve the understanding of the interplay of toxicity pathways and identify useful biomarkers for safety assessment and disease biology. Ultimately, the aggregation of quality-controlled assay data could yield new hypotheses for toxicological studies and develop better methods to assess chemical safety in humans and environment.

\section{Acknowledgements}

This work was supported by the US Environmental Protection Agency (Interagency Agreement \#Y3-HG-7026-03) and the interagency agreement IAG \#NTR 12003 from the NIEHS/Division of the NTP to the NCATS, National Institutes of Health.

\section{References}

ACToR [online] http://actor.epa.gov/actor/faces/ACToRHome.jsp (accessed 23 December 2015).

CEBS [online] http://tools.niehs.nih.gov/cebs3/ui/ (accessed 23 December 2015).

PubChem [online] http://pubchem.ncbi.nlm.nih.gov/ (accessed 23 December 2015).

Tox21 Applications [online] http://tripod.nih.gov/tox (accessed 23 December 2015).

Abdo, N., Xia, M., Brown, C.C., Kosyk, O., Huang, R., Sakamuru, S., Zhou, Y-H., Jack, J.R., Gallins, P. and Xia, K. (2015) 'Population-based in vitro hazard and concentration - response assessment of chemicals: the 1000 genomes high-throughput screening study', Environmental Health Perspectives, Vol. 123, No. 5, pp.458-466.

Attene-Ramos, M., Austin, C. and Xia, M. (2013a) High Throughput Screening, 3rd ed., Elsevier, Amsterdam. 
Attene-Ramos, M.S., Huang, R., Sakamuru, S., Witt, K.L., Beeson, G.C., Shou, L., Schnellmann, R.G., Beeson, C.C., Tice, R.R. and Austin, C.P. (2013b) 'Systematic study of mitochondrial toxicity of environmental chemicals using quantitative high throughput screening', Chemical Research In Toxicology, Vol. 26, No. 9, pp.1323-1332.

Attene-Ramos, M.S., Miller, N., Huang, R., Michael, S., Itkin, M., Kavlock, R.J., Austin, C.P., Shinn, P., Simeonov, A. and Tice, R.R. (2013c) 'The Tox21 robotic platform for the assessment of environmental chemicals - from vision to reality', Drug Discovery Today, Vol. 18, No. 15, pp.716-723.

Attene-Ramos, M., Huang, S.R., Michael, S., Witt, K.L., Richard, A., Tice, R.R., Simeonov, A., Austin, C.P. and Xia, M. (2015) 'Profiling of the Tox21 chemical collection for mitochondrial function to identify compounds that acutely decrease mitochondrial membrane potential', Environ Health Perspect., Vol. 123, No. 1, pp.49-56.

Becker, R.A., Friedman, K.P., Simon, T.W., Marty, M.S., Patlewicz, G. and Rowlands, J.C. (2015) 'An exposure: activity profiling method for interpreting high-throughput screening data for estrogenic activity - proof of concept', Regulatory Toxicology and Pharmacology, Vol. 71, No. 3, pp.398-408.

Bi, K., Nishihara, K., Machleidt, T., Hermanson, S., Wang, J., Sakamuru, S., Huang, R. and Xia, M. (2015) 'Identification of known drugs targeting the endoplasmic reticulum stress response', Analytical and Bioanalytical Chemistry, Vol. 407, No. 18, pp.5343-5351.

Brown, K.K., Henke, B.R., Blanchard, S.G., Cobb, J.E., Mook, R., Kaldor, I., Kliewer, S.A., Lehmann, J.M., Lenhard, J.M. and Harrington, W.W. (1999) 'A novel n-aryl tyrosine activator of peroxisome proliferator-activated receptor-gamma reverses the diabetic phenotype of the Zucker diabetic fatty rat', Diabetes, Vol. 48, No. 7, pp.1415-1424.

Burow, M.E., Tang, Y., Collins-Burow, B.M., Krajewski, S., Reed, J.C., Mclachlan, J.A. and Beckman, B.S. (1999) 'Effects of environmental estrogens on tumor necrosis factor $\alpha$-mediated apoptosis in Mcf-7 cells', Carcinogenesis, Vol. 20, No. 11, pp.2057-2061.

Casals-Casas, C. and Desvergne, B. (2011) 'Endocrine disruptors: from endocrine to metabolic disruption', Annual Review of Physiology, Vol. 73, pp.135-162.

Chang, X., Kleinstreuer, N., Ceger, P., Hsieh, J-H., Allen, D. and Casey, W. (2015) 'Application of reverse dosimetry to compare in vitro and in vivo estrogen receptor activity', Applied In Vitro Toxicology, Vol. 1, No. 1, pp.33-44.

Chen, S., Hsieh, J.H., Huang, R., Sakamuru, S., Hsin, L.Y., Xia, M., Shockley, K.R., Auerbach, S., Kanaya, N., Lu, H., Svoboda, D., Witt, K.L., Merrick, B.A., Teng, C.T. and Tice, R.R. (2015) 'Cell-based high-throughput screening for aromatase inhibitors in the Tox $2110 \mathrm{~K}$ library', Toxicological Sciences, Vol. 147, No. 2, pp.446-457.

Chen, S., Zhou, D., Hsin, L-Y., Kanaya, N., Wong, C., Yip, R., Sakamuru, S., Xia, M., Yuan, Y-C. and Witt, K. (2014) 'Aroer tri-screen is a biologically relevant assay for endocrine disrupting chemicals modulating the activity of aromatase and/or the estrogen receptor', Toxicological Sciences, Vol. 139, No. 1, pp.198-209.

Cho, M-H., Niles, A., Huang, R., Inglese, J., Austin, C.P., Riss, T. and Xia, M. (2008) 'A bioluminescent cytotoxicity assay for assessment of membrane integrity using a proteolytic biomarker', Toxicology in Vitro, Vol. 22, No. 4, pp.1099-1106.

Christopoulos, A., May, L., Avlani, V. and Sexton, P. (2004) 'G-protein-coupled receptor allosterism: the promise and the problem (S)', Biochemical Society Transactions, Vol. 32, No. Pt 5, pp.873-877.

Coon, M.J. (2005) 'Cytochrome P450: nature's most versatile biological catalyst', Annual Review of Pharmacology and Toxicology, Vol. 45, pp.1-25.

Davies, S.S., Pontsler, A.V., Marathe, G.K., Harrison, K.A., Murphy, R.C., Hinshaw, J.C., Prestwich, G.D., Hilaire, A.S., Prescott, S.M. and Zimmerman, G.A. (2001) 'Oxidized alkyl phospholipids are specific, high affinity peroxisome proliferator-activated receptor $\Gamma$ ligands and agonists', Journal of Biological Chemistry, Vol. 276, No. 19, pp.16015-16023.

Davis, R.E., Zhang, Y-Q., Southall, N., Staudt, L.M., Austin, C.P., Inglese, J. and Auld, D.S. (2007) 'A cell-based assay for I K B A stabilization using a two-color dual luciferase-based sensor', Assay and Drug Development Technologies, Vol. 5, No. 1, pp.85-104. 
Fox, J.T., Sakamuru, S., Huang, R., Teneva, N., Simmons, S.O., Xia, M., Tice, R.R., Austin, C.P. and Myung, K. (2012) 'High-throughput genotoxicity assay identifies antioxidants as inducers of DNA damage response and cell death', Proceedings of the National Academy of Sciences, Vol. 109, No. 14, pp.5423-5428.

Francis, G.A., Fayard, E., Picard, F. and Auwerx, J. (2003) 'Nuclear receptors and the control of metabolism', Annual Review of Physiology, Vol. 65, No. 1, pp.261-311.

Freitas, J., Miller, N., Mengeling, B.J., Xia, M., Huang, R., Houck, K., Rietjens, I.M., Furlow, J.D. and Murk, A.J. (2014) 'Identification of thyroid hormone receptor active compounds using a quantitative high-throughput screening platform', Current Chemical Genomics and Translational Medicine, Vol. 8, pp.36-46.

Glickman, J.F., Wu, X., Mercuri, R., Illy, C., Bowen, B.R., He, Y. and Sills, M. (2002) 'A comparison of alphascreen, Tr-Fret, and Trf as assay methods for Fxr nuclear receptors', Journal of Biomolecular Screening, Vol. 7, No. 1, pp.3-10.

Greaves, P., Williams, A. and Eve, M. (2004) 'First dose of potential new medicines to humans: how animals help', Nature Reviews Drug Discovery, Vol. 3, No. 3, pp.226-236.

Hancock, M.K., Xia, M., Frey, E.S., Sakamuru, S. and Bi, K. (2009) 'Hts-compatible B-lactamase transcriptional reporter gene assay for interrogating the heat shock response pathway', Current Chemical Genomics, Vol. 3, pp.1-6.

Hill, A.V. (1910) 'The possible effects of the aggregation of the molecules of haemoglobin on its dissociation curves', Journal of Physiology (London), Vol. 40, pp.4-7.

Hsu, C-W., Zhao, J., Huang, R., Hsieh, J-H., Hamm, J., Chang, X., Houck, K. and Xia, M. (2014) 'Quantitative high-throughput profiling of environmental chemicals and drugs that modulate farnesoid X receptor', Scientific Reports, Vol. 4, p.6437.

Hsu, C.W., Huang, R., Khuc, T., Shou, D., Bullock, J., Grooby, S., Griffin, S., Zou, C., Little, A., Astley, H. and Xia, M. (2016a) 'Identification of approved and investigational drugs that inhibit hypoxia-inducible factor-1', Oncotargets, Vol. 7, No. 7, pp.8172-8183.

Hsu, C.W., Shou, D., Huang, R., Khuc, T., Dai, S., Zheng, W., Klumpp-Thomas, C. and Xia, M. (2016b) 'Identification of HDAC inhibitors using a cell-based HDAC I/II assay', Journal of Biomolecular Screening, in press.

Huang, R., Sakamuru, S., Martin, M.T., Reif, D.M., Judson, R.S., Houck, K.A., Casey, W., Hsieh, J-H., Shockley, K.R. and Ceger, P. (2014) 'Profiling of the Tox21 10k compound library for agonists and antagonists of the estrogen receptor alpha signaling pathway', Scientific Reports, Vol. 4, No. 5664, pp.1-9.

Huang, R., Southall, N., Cho, M-H., Xia, M., Inglese, J. and Austin, C.P. (2008) 'Characterization of diversity in toxicity mechanism using in vitro cytotoxicity assays in quantitative high throughput screening', Chemical Research In Toxicology, Vol. 21, No. 3, pp.659-667.

Huang, R., Southall, N., Wang, Y., Yasgar, A., Shinn, P., Jadhav, A., Nguyen, D-T. and Austin, C.P. (2011a) 'The NCGC pharmaceutical collection: a comprehensive resource of clinically approved drugs enabling repurposing and chemical genomics', Science Translational Medicine, Vol. 3, No. 80, pp.80ps16-80ps16.

Huang, R., Xia, M., Cho, M-H., Sakamuru, S., Shinn, P., Houck, K.A., Dix, D.J., Judson, R.S., Witt, K.L. and Kavlock, R.J. (2011b) 'Chemical genomics profiling of environmental chemical modulation of human nuclear receptors', Environmental Health Perspectives, Vol. 119, No. 8, pp.1142-1148.

Huang, R., Southall, N., Xia, M., Cho, M-H., Jadhav, A., Nguyen, D-T., Inglese, J., Tice, R.R. and Austin, C.P. (2009) 'Weighted feature significance (Wfs): a simple, interpretable model of compound toxicity based on the statistical enrichment of structural features', Toxicological Sciences, Vol. 112, No. 2, pp.385-393.

Huang, R., Xia, M., Nguyen, D., Zhao, T., Sakamuru, S., Zhao, J., Shahane, S., Rossoshek, A. and Simeonov, A. (2015) 'Tox21Challenge to build predictive models of nuclear receptor and stress response pathways as mediated by exposure to environmental chemicals and drugs', Frontiers in Environmental Science, Vol. 3, p.85, doi: 10.3389/fenvs.2015.00085. 
Iijima-Ando, K., Wu, P., Drier, E.A., Iijima, K. and Yin, J.C. (2005) 'Camp-response elementbinding protein and heat-shock protein 70 additively suppress polyglutamine-mediated toxicity in drosophila', Proceedings of the National Academy of Sciences of the United States of America, Vol. 102, No. 29, pp.10261-10266.

Inglese, J., Auld, D.S., Jadhav, A., Johnson, R.L., Simeonov, A., Yasgar, A., Zheng, W. and Austin, C.P. (2006) 'Quantitative high-throughput screening: a titration-based approach that efficiently identifies biological activities in large chemical libraries', Proceedings of the National Academy of Sciences, Vol. 103, No. 31, pp.11473-11478.

Isaacs, J.S., Jung, Y-J., Mimnaugh, E.G., Martinez, A., Cuttitta, F. and Neckers, L.M. (2002) 'Hsp90 regulates a Von Hippel lindau-independent hypoxia-inducible factor- $1 \alpha$-degradative pathway', Journal of Biological Chemistry, Vol. 277, No. 33, pp.29936-29944.

Johnson, R.L., Huang, R., Jadhav, A., Southall, N., Wichterman, J., Macarthur, R., Xia, M., Bi, K., Printen, J. and Austin, C.P. (2009) 'A quantitative high-throughput screen for modulators of Il-6 signaling: a model for interrogating biological networks using chemical libraries', Molecular BioSystems, Vol. 5, No. 9, pp.1039-1050.

Johnson, R.L., Huang, W., Jadhav, A., Austin, C.P., Inglese, J. and Martinez, E.D. (2008) 'A quantitative high-throughput screen identifies potential epigenetic modulators of gene expression', Analytical Biochemistry, Vol. 375, No. 2, pp.237-248.

Johnson, R.L., Hwang, J.Y., Arnold, L.A., Huang, R., Wichterman, J., Augustinaite, I., Austin, C.P., Inglese, J., Guy, R.K. and Huang, W. (2011) 'A quantitative high-throughput screen identifies novel inhibitors of the interaction of thyroid receptor B with a peptide of steroid receptor coactivator 2', Journal of Biomolecular Screening, Vol. 16, No. 6, pp.618-627.

Judson, R., Richard, A., Dix, D., Houck, K., Elloumi, F., Martin, M., Cathey, T., Transue, T.R., Spencer, R. and Wolf, M. (2008) 'Actor - aggregated computational toxicology resource', Toxicology and Applied Pharmacology, Vol. 233, No. 1, pp.7-13.

Judson, R.S., Houck, K.A., Kavlock, R.J., Knudsen, T.B., Martin, M.T., Mortensen, H.M., Reif, D.M., Rotroff, D.M., Shah, I. and Richard, A.M. (2010a) 'In vitro screening of environmental chemicals for targeted testing prioritization: the ToxCast project', Environmental Health Perspectives, Vol. 118, No. 4, pp.485-492.

Judson, R.S., Martin, M.T., Reif, D.M., Houck, K.A., Knudsen, T.B., Rotroff, D.M., Xia, M., Sakamuru, S., Huang, R. and Shinn, P. (2010b) 'Analysis of eight oil spill dispersants using rapid, in vitro tests for endocrine and other biological activity', Environmental Science \& Technology, Vol. 44, No. 15, pp.5979-5985.

Kanebratt, K.P. and Andersson, T.B. (2008) 'Evaluation of heparg cells as an in vitro model for human drug metabolism studies', Drug Metabolism and Disposition, Vol. 36, No. 7, pp.1444-1452.

Knight, A.W., Little, S., Houck, K., Dix, D., Judson, R., Richard, A., Mccarroll, N., Akerman, G., Yang, C. and Birrell, L. (2009) 'Evaluation of high-throughput genotoxicity assays used in profiling the US EPA Toxcast ${ }^{\mathrm{TM}}$ chemicals', Regulatory Toxicology and Pharmacology, Vol. 55, No. 2, pp.188-199.

Leister, K.P., Huang, R., Goodwin, B.L., Chen, A., Austin, C.P. and Xia, M. (2011) 'Two high throughput screen assays for measurement of Tnf-A in Thp-1 cells', Current Chemical Genomics, Vol. 5, pp.21-29.

Liu, K., Southall, N., Titus, S.A., Inglese, J., Eskay, R.L., Shinn, P., Austin, C.P., Heilig, M.A. and Zheng, W. (2010) 'A multiplex calcium assay for identification of Gpcr agonists and antagonists', Assay and Drug Development Technologies, Vol. 8, No. 3, pp.362-374.

Liu, K., Titus, S., Southall, N., Zhu, P., Inglese, J., Austin, C.P. and Zheng, W. (2008) 'Comparison on functional assays for Gq-coupled Gpcrs by measuring inositol monophospate-1 and intracellular calcium in 1536-well plate format', Current Chemical Genomics, Vol. 1, pp.70-78.

Lock, E.F., Abdo, N., Huang, R., Xia, M., Kosyk, O., O’Shea, S.H., Zhou, Y.H., Sedykh, A., Tropsha, A., Austin, C.P., Tice, R.R., Wright, F.A. and Rusyn, I. (2012) 'Quantitative high-throughput screening for chemical toxicity in a population-based in vitro model', Toxicol Sci., Vol. 126, No. 2, pp.578-588. 
Long, Y., Lin, Z., Xia, M., Zheng, W. and Li, Z. (2013) 'Mechanism of herg potassium channel inhibition by tetra-N-octylammonium bromide and benzethonium chloride', Toxicology and Applied Pharmacology, Vol. 267, No. 2, pp.155-166.

Lynch, C., Pan, Y., Li, L., Ferguson, S.S., Xia, M., Swaan, P.W. and Wang, H. (2013) 'Identification of novel activators of constitutive androstane receptor from FDA-approved drugs by integrated computational and biological approaches', Pharmaceutical Research, Vol. 30, No. 2, pp.489-501.

Martin, M.T., Knudsen, T.B., Reif, D.M., Houck, K.A., Judson, R.S., Kavlock, R.J. and Dix, D.J. (2011) 'Predictive model of rat reproductive toxicity from Toxcast high throughput screening', Biology of Reproduction, Vol. 85, No. 2, pp.327-339.

Miller, S.C., Huang, R., Sakamuru, S., Shukla, S.J., Attene-Ramos, M.S., Shinn, P., van Leer, D., Leister, W., Austin, C.P. and Xia, M. (2010) 'Identification of known drugs that act as inhibitors of $\mathrm{Nf}-\mathrm{Kb}$ signaling and their mechanism of action', Biochemical Pharmacology, Vol. 79, No. 9, pp.1272-1280.

Moeller, T.A., Shukla, S.J. and Xia, M. (2012) 'Assessment of compound hepatotoxicity using human plateable cryopreserved hepatocytes in a 1536-well-plate format', Assay and Drug Development Technologies, Vol. 10, No. 1, pp.78-87.

Nishihara, K., Huang, R., Zhao, J., Shahane, S., Witt, K.L., Smith-Roe, S.L., Tice, R.R., Takeda, S. and Xia, M. (2016) 'Identification of genotoxic compounds using isogenic DNA repair deficient DT40 cell lines on a quantitative high throughput screening (qHTS) platform', Mutagenesis, Vol. 31, No. 1, pp.69-81, doi:10.1093/mutage/gew055.

Odermatt, A., Gumy, C., Atanasov, A.G. and Dzyakanchuk, A.A. (2006) 'Disruption of glucocorticoid action by environmental chemicals: potential mechanisms and relevance', The Journal of Steroid Biochemistry and Molecular Biology, Vol. 102, No. 1, pp.222-231.

Politi, R., Rusyn, I. and Tropsha, A. (2014) 'Prediction of binding affinity and efficacy of thyroid hormone receptor ligands using QSAR and structure-based modeling methods', Toxicology and Applied Pharmacology, Vol. 280, No. 1, pp.177-189.

Potera, C. (2015) 'Potential mitochondrial toxicants: Tox21 screen identifies structures of interest', Environmental Health Perspectives, Vol. 123, No. 1, p.A23.

Resenberger, U.K., Müller, V., Munter, L.M., Baier, M., Multhaup, G., Wilson, M.R., Winklhofer, K.F. and Tatzelt, J. (2012) 'The heat shock response is modulated by and interferes with toxic effects of scrapie prion protein and amyloid B', Journal of Biological Chemistry, Vol. 287, No. 52, pp.43765-43776.

Rotroff, D.M., Dix, D.J., Houck, K.A., Knudsen, T.B., Martin, M.T., Mclaurin, K.W., Reif, D.M., Crofton, K.M., Singh, A.V. and Xia, M. (2013) 'Using in vitro high throughput screening assays to identify potential endocrine-disrupting chemicals', Environmental Health Perspectives, Vol. 121, No. 1, pp.7-14.

Sakamuru, S., Li, X., Attene-Ramos, M.S., Huang, R., Lu, J., Shou, L., Shen, M., Tice, R.R., Austin, C.P. and Xia, M. (2012) 'Application of a homogenous membrane potential assay to assess mitochondrial function', Physiological Genomics, Vol. 44, No. 9, pp.495-503.

Schoonjans, F., Depuydt, C. and Comhaire, F. (1996) 'Presentation of receiver-operating characteristics (Roc) plots', Clinical Chemistry, Vol. 42, No. 6, pp.986-987.

Shahane, S.A., Huang, R., Gerhold, D., Baxa, U., Austin, C.P. and Xia, M. (2014) 'Detection of phospholipidosis induction a cell-based assay in high-throughput and high-content format', Journal of Biomolecular Screening, Vol. 19, No. 1, pp.66-76.

Shukla, S.J., Huang, R., Austin, C.P. and Xia, M. (2010) 'The future of toxicity testing: a focus on in vitro methods using a quantitative high-throughput screening platform', Drug Discovery Today, Vol. 15, No. 23, pp.997-1007.

Shukla, S.J., Huang, R., Simmons, S.O., Tice, R.R., Witt, K.L., Vanleer, D., Ramabhadran, R., Austin, C.P. and Xia, M. (2012) 'Profiling environmental chemicals for activity in the antioxidant response element signaling pathway using a high throughput screening approach', Environmental Health Perspectives, Vol. 120, No. 8, pp.1150-1156. 
Shukla, S.J., Nguyen, D-T., Macarthur, R., Simeonov, A., Frazee, W.J., Hallis, T.M., Marks, B.D., Singh, U., Eliason, H.C. and Printen, J. (2009) 'Identification of pregnane X receptor ligands using time-resolved fluorescence resonance energy transfer and quantitative high-throughput screening', Assay and Drug Development Technologies, Vol. 7, No. 2, pp.143-169.

Shukla, S.J., Sakamuru, S., Huang, R., Moeller, T.A., Shinn, P., Vanleer, D., Auld, D.S., Austin, C.P. and Xia, M. (2011) 'Identification of clinically used drugs that activate pregnane X receptors', Drug Metabolism and Disposition, Vol. 39, No. 1, pp.151-159.

Simeonov, A., Jadhav, A., Thomas, C.J., Wang, Y., Huang, R., Southall, N.T., Shinn, P., Smith, J., Austin, C.P. and Auld, D.S. (2008) 'Fluorescence spectroscopic profiling of compound libraries', Journal of Medicinal Chemistry, Vol. 51, No. 8, pp.2363-2371.

Sipes, N.S., Martin, M.T., Reif, D.M., Kleinstreuer, N.C., Judson, R.S., Singh, A.V., Chandler, K.J., Dix, D.J., Kavlock, R.J. and Knudsen, T.B. (2011) 'Predictive models of prenatal developmental toxicity from toxcast high-throughput screening data', Toxicological Sciences, Vol. 124, No. 1, pp.109-127.

Southall, N.T., Jadhav, A., Huang, R., Nguyen, T. and Wang, Y. (2009) 'Enabling the large-scale analysis of quantitative high-throughput screening data', in Seethala, R. and Zhang, L. (Eds.): Handbook of Drug Screening, 2nd ed., CRC Press, New York.

Sun, H. (2004) 'A universal molecular descriptor system for prediction of logp, logs, logbb, and absorption', Journal of Chemical Information and Computer Sciences, Vol. 44, No. 2, pp.748-757.

Sun, H., Shahane, S., Xia, M., Austin, C.P. and Huang, R. (2012a) 'Structure based model for the prediction of phospholipidosis induction potential of small molecules', Journal of Chemical Information and Modeling, Vol. 52, No. 7, pp.1798-1805.

Sun, H., Veith, H., Xia, M., Austin, C.P., Tice, R.R. and Huang, R. (2012b) 'Prediction of cytochrome P450 profiles of environmental chemicals with Qsar models built from drug-like molecules', Molecular Informatics, Vol. 31, Nos. 11-12, pp.783-792.

Sun, H., Xia, M., Austin, C.P. and Huang, R. (2012c) 'Paradigm shift in toxicity testing and modeling', The AAPS Journal, Vol. 14, No. 3, pp.473-480.

Sun, H., Veith, H., Xia, M., Austin, C.P. and Huang, R. (2011) 'Predictive models for cytochrome P450 isozymes based on quantitative high throughput screening data', Journal of Chemical Information and Modeling, Vol. 51, No. 10, pp.2474-2481.

Teng, C., Goodwin, B., Shockley, K., Xia, M., Huang, R., Norris, J., Merrick, B.A., Jetten, A.M., Austin, C.P. and Tice, R.R. (2013) 'Bisphenol A affects androgen receptor function via multiple mechanisms’, Chemico-Biological Interactions, Vol. 203, No. 3, pp.556-564.

Tice, R.R., Austin, C.P., Kavlock, R.J. and Bucher, J.R. (2013) 'Improving the human hazard characterization of chemicals: a Tox21 update', Environmental Health Perspectives, Vol. 121, No. 7, pp.756-765.

Titus, S., Neumann, S., Zheng, W., Southall, N., Michael, S., Klumpp, C., Yasgar, A., Shinn, P., Thomas, C.J. and Inglese, J. (2008a) 'Quantitative high-throughput screening using a live-cell camp assay identifies small-molecule agonists of the Tsh receptor', Journal of Biomolecular Screening, Vol. 13, No. 2, pp.120-127.

Titus, S.A., Li, X., Southall, N., Lu, J., Inglese, J., Brasch, M., Austin, C.P. and Zheng, W. (2008b) 'A cell-based Pde4 assay in 1536-well plate format for high-throughput screening', Journal of Biomolecular Screening, Vol. 13, No. 7, pp.609-618.

Titus, S.A., Beacham, D., Shahane, S.A., Southall, N., Xia, M., Huang, R., Hooten, E., Zhao, Y., Shou, L. and Austin, C.P. (2009) 'A new homogeneous high-throughput screening assay for profiling compound activity on the human ether-a-go-go-related gene channel', Analytical Biochemistry, Vol. 394, No. 1, pp.30-38.

Veith, H., Southall, N., Huang, R., James, T., Fayne, D., Artemenko, N., Shen, M., Inglese, J., Austin, C.P. and Lloyd, D.G. (2009) 'Comprehensive characterization of cytochrome P450 isozyme selectivity across chemical libraries', Nature Biotechnology, Vol. 27, No. 11, pp.1050-1055. 
Wang, Y., Jadhav, A., Southal, N., Huang, R. and Nguyen, D-T. (2010) 'A grid algorithm for high throughput fitting of dose-response curve data', Current Chemical Genomics, Vol. 4, p.57.

Waters, M., Stasiewicz, S., Merrick, B.A., Tomer, K., Bushel, P., Paules, R., Stegman, N., Nehls, G., Yost, K.J. and Johnson, C.H. (2008) 'CEBS - chemical effects in biological systems: a public data repository integrating study design and toxicity data with microarray and proteomics data', Nucleic Acids Research, Vol. 36, No. 1, pp.D892-D900.

Xia, M., Bi, K., Huang, R., Cho, M-H., Sakamuru, S., Miller, S.C., Li, H., Sun, Y., Printen, J. and Austin, C.P. (2009a) 'Identification of small molecule compounds that inhibit the Hif-1 signaling pathway', Mol Cancer, Vol. 8, No. 117, pp.1476-4598.

Xia, M., Guo, V., Huang, R., Inglese, J., Nirenberg, M. and Austin, C.P. (2009b) 'A cell-based B-lactamase reporter gene assay for the creb signaling pathway', Current Chemical Genomics, Vol. 3, No. 1, pp.7-12.

Xia, M., Huang, R., Guo, V., Southall, N., Cho, M-H., Inglese, J., Austin, C.P. and Nirenberg, M. (2009c) 'Identification of compounds that potentiate creb signaling as possible enhancers of long-term memory', Proceedings of the National Academy of Sciences, Vol. 106, No. 7, pp.2412-2417.

Xia, M., Huang, R., Sun, Y., Semenza, G.L., Aldred, S.F., Witt, K.L., Inglese, J., Tice, R.R. and Austin, C.P. (2009d) 'Identification of chemical compounds that induce Hif- $1 \alpha$ activity', Toxicological Sciences, Vol. 112, No. 1, pp.153-163.

Xia, M., Guo, V., Huang, R., Shahane, S.A., Austin, C.P., Nirenberg, M. and Sharma, S.K. (2011a) 'Inhibition of morphine-induced camp overshoot: a cell-based assay model in a highthroughput format', Cellular and Molecular Neurobiology, Vol. 31, No. 6, pp.901-907.

Xia, M., Shahane, S.A., Huang, R., Titus, S.A., Shum, E., Zhao, Y., Southall, N., Zheng, W., Witt, K.L. and Tice, R.R. (2011b) 'Identification of quaternary ammonium compounds as potent inhibitors of herg potassium channels', Toxicology and Applied Pharmacology, Vol. 252, No. 3, pp.250-258.

Xia, M., Huang, R., Witt, K.L., Southall, N., Fostel, J., Cho, M., Jadhav, A., Smith, C.S., Inglese, J. and Portier, C.J. (2008) 'Compound cytotoxicity profiling using quantitative high-throughput screening', Environmental Health Perspectives, Vol. 116, No. 3, pp.284-291.

Yamamoto, K.N., Hirota, K., Kono, K., Takeda, S., Sakamuru, S., Xia, M., Huang, R., Austin, C.P., Witt, K.L. and Tice, R.R. (2011) 'Characterization of environmental chemicals with potential for DNA damage using isogenic DNA repair - deficient chicken Dt40 cell lines', Environmental and Molecular Mutagenesis, Vol. 52, No. 7, pp.547-561.

Yang, X. (2010) 'A wheel of time: the circadian clock, nuclear receptors, and physiology', Genes \& Development, Vol. 24, No. 8, pp.741-747.

Yi, F., Zhu, P., Southall, N., Inglese, J., Austin, C.P., Zheng, W. and Regan, L. (2009) 'An Alphascreen ${ }^{\mathrm{TM}}$-based high-throughput screen to identify inhibitors of Hsp90-cochaperone interaction', Journal of Biomolecular Screening, Vol. 14, No. 3, pp.273-281.

Zang, Q., Rotroff, D.M. and Judson, R.S. (2013) 'Binary classification of a large collection of environmental chemicals from estrogen receptor assays by quantitative structure - activity relationship and machine learning methods', Journal of Chemical Information and Modeling, Vol. 53, No. 12, pp.3244-3261.

Zhang, J-H., Chung, T.D. and Oldenburg, K.R. (1999) 'A simple statistical parameter for use in evaluation and validation of high throughput screening assays', Journal of Biomolecular Screening, Vol. 4, No. 2, pp.67-73.

Zhu, P.J., Zheng, W., Auld, D.S., Jadhav, A., Macarthur, R., Olson, K.R., Peng, K., Dotimas, H., Austin, C.P. and Inglese, J. (2008) 'A miniaturized glucocorticoid receptor translocation assay using enzymatic fragment complementation evaluated with Qhts', Combinatorial Chemistry \& High Throughput Screening, Vol. 11, No. 7, pp.545-559. 